\title{
Adult Hippocampal Neurogenesis Modulates Fear Learning through Associative and Nonassociative Mechanisms
}

\author{
DDong-oh Seo, ${ }^{1,2}$ Mary Ann Carillo, ${ }^{3}$ Sean Chih-Hsiung Lim, ${ }^{4}$ Kenji F. Tanaka, ${ }^{5}$ and Michael R. Drew ${ }^{1}$ \\ ${ }^{1}$ Center for Learning and Memory, Department of Neuroscience, and ${ }^{2}$ Department of Psychology, The University of Texas at Austin, Austin, Texas 78712, \\ ${ }^{3}$ Barnard College, Columbia University, New York, New York 10032, ${ }^{4}$ Division of Integrative Neuroscience, New York State Psychiatric Institute/Research \\ Foundation for Mental Hygiene, New York, New York 10027, and 5Department of Neuropsychiatry, School of Medicine, Keio University, Tokyo 160-8582, Japan
}

Adult hippocampal neurogenesis is believed to support hippocampus-dependent learning and emotional regulation. These putative functions of adult neurogenesis have typically been studied in isolation, and little is known about how they interact to produce adaptive behavior. We used trace fear conditioning as a model system to elucidate mechanisms through which adult hippocampal neurogenesis modulates processing of aversive experience. To achieve a specific ablation of neurogenesis, we generated transgenic mice that express herpes simplex virus thymidine kinase specifically in neural progenitors and immature neurons. Intracerebroventricular injection of the prodrug ganciclovir caused a robust suppression of neurogenesis without suppressing gliogenesis. Neurogenesis ablation via this method or targeted $\mathrm{x}$-irradiation caused an increase in context conditioning in trace but not delay fear conditioning. Data suggest that this phenotype represents opposing effects of neurogenesis ablation on associative and nonassociative components of fear learning. Arrest of neurogenesis sensitizes mice to nonassociative effects of fear conditioning, as evidenced by increased anxiety-like behavior in the open field after (but not in the absence of) fear conditioning. In addition, arrest of neurogenesis impairs associative trace conditioning, but this impairment can be masked by nonassociative fear. The results suggest that adult neurogenesis modulates emotional learning via two distinct but opposing mechanisms: it supports associative trace conditioning while also buffering against the generalized fear and anxiety caused by fear conditioning.

Key words: adult neurogenesis; anxiety; dentate gyrus; doublecortin; fear conditioning; trace conditioning

Significance Statement

The role of adult hippocampal neurogenesis in fear learning is controversial, with some studies suggesting neurogenesis is needed for aspects of fear learning and others suggesting it is dispensable. We generated transgenic mice in which neural progenitors can be selectively and inducibly ablated. Our data suggest that adult neurogenesis supports fear learning through two distinct mechanisms: it supports the ability to learn associations between traumatic events (unconditioned stimuli) and predictors (conditioned stimuli) while also buffering against nonassociative, anxiogenic effects of a traumatic experience. As a result, arrest of neurogenesis can enhance or impair learned fear depending on intensity of the traumatic experience and the extent to which it recruits associative versus nonassociative learning.

\section{Introduction}

There is growing evidence that adult hippocampal neurogenesis contributes to both cognition and emotional regulation. Selective

Received Feb. 4, 2015; revised June 25, 2015; accepted July 7, 2015.

Author contributions: D.-0.S. and M.R.D. designed research; D.-0.S., M.A.C., S.C.-H.L., and M.R.D. performed research; K.F.T. and M.R.D. contributed unpublished reagents/analytic tools; D.-0.S. and M.R.D. analyzed data; D.-O.S. and M.R.D. wrote the paper.

This work was supported by National Institutes of Health Grant R01MH102595. We thank Michael Nguyen and Francis Shue for their assistance with behavioral testing.

The authors declare no competing financial interests.

Correspondence should be addressed to Michael R. Drew, Center for Learning and Memory, Department of Neuroscience, The University of Texas at Austin, Austin, TX 78712. E-mail: mdrew@utexas.edu.

DOI:10.1523/JNEUROSCI.0483-15.2015

Copyright $\odot 2015$ the authors $\quad 0270-6474 / 15 / 3511330-16 \$ 15.00 / 0$ suppression of adult neurogenesis impairs performance on some hippocampus-dependent cognitive tasks (Shors et al., 2002; Clelland et al., 2009; Deng et al., 2009; Drew et al., 2010; Sahay et al., 2011; Tronel et al., 2012; Swan et al., 2014), abrogates the behavioral effects of antidepressant medications (Santarelli et al., 2003; Airan et al., 2007; David et al., 2009), and impairs feedback regulation of the hypothalamic-pituitary-adrenal (HPA) axis (Schloesser et al., 2010; Snyder et al., 2011). The roles in cognition, mood, and anxiety have typically been studied in isolation, and it is unknown to what extent they reflect functionally distinct contributions of adult neurogenesis to behavior versus a common perturbation of information processing.

One mechanism through which neurogenesis may influence both cognition and emotional regulation is Pavlovian condition- 
ing. In Pavlovian conditioning, an animal learns to anticipate motivationally and emotionally salient events, managing its behavioral and physiological responses to them. When there is a simple relation between a discrete predictor (conditioned stimulus; CS) and an unconditioned stimulus (US), learning can be accomplished by subcortical mechanisms. However, the hippocampus is typically required when the predictor is a context (Rudy et al., 2004) or the CS and US are temporally discontiguous, such as in trace conditioning (Solomon et al., 1986). Adult neurogenesis has been implicated in both of these hippocampusdependent forms of conditioning, but the literature also contains studies that failed to support a role for neurogenesis (Leuner et al., 2006a; Castilla-Ortega et al., 2011). Literature on trace conditioning is a representative example. Trace conditioning rescues newborn hippocampal neurons from death (Gould et al., 1999; Leuner et al., 2004, 2006b), but the suppression of neurogenesis has been reported to impair, enhance, or have no effect on trace conditioning (Cuppini et al., 2006; Achanta et al., 2009; Jaholkowski et al., 2009; Guo et al., 2011). Differences in the specificity or penetrance of the methods of suppressing neurogenesis almost certainly contribute to the conflicts among studies. Most existing methods of neurogenesis ablation target multipotent progenitors and affect the genesis of neurons and non-neuronal cell types to varying extents (Monje et al., 2002; Imayoshi et al., 2011).

It is also likely that emotional factors modulate the effects of neurogenesis ablation on Pavlovian conditioning. If, as recent studies suggest, adult-born neurons have a role in buffering the hormonal and behavioral responses to stress (Hayashi et al., 2008; Schloesser et al., 2010; Castilla-Ortega et al., 2011; Snyder et al., 2011), then in aversive tasks, such as trace fear conditioning, the behavioral effects of arresting adult hippocampal neurogenesis may reflect a complex interaction between emotional and cognitive phenotypes.

Here, we investigate the role of adult hippocampal neurogenesis in trace and delay fear conditioning using a new, highly specific method of neurogenesis ablation. We created transgenic mice in which herpes simplex virus thymidine kinase (HSV-TK) is expressed under the doublecortin (DCX) promoter (DCX-TK). Administration of the prodrug ganciclovir (GCV) to DCX-TK mice rapidly suppresses neurogenesis without ablating quiescent DCX-expressing neurons or impairing the production of glia. We show that arrest of adult hippocampal neurogenesis can enhance or impair aspects of trace fear conditioning depending on the nature of the conditioning protocol. When the procedure engenders robust nonassociative changes in fear expression, neurogenesis-arrested mice display elevated fear behavior; in a trace-conditioning procedure that minimizes nonassociative plasticity, neurogenesis-arrested mice display impaired associative fear. These data suggest that arrest of adult neurogenesis affects fear conditioning through opposing associative and nonassociative mechanisms.

\section{Materials and Methods}

DCX-TK transgenic mice

A BAC clone (RP23-462G16) that contained the entire mouse $d c x$ gene, plus at least $50 \mathrm{~kb}$ of upstream and downstream flanking sequences, was obtained from the BACPAC Resources Center (http://bacpac.chori.org). The DCX promoter was selected because DCX is expressed in lineagerestricted neural progenitor cells and immature adult-born neurons (Brown et al., 2003). The pBADTcTypeG plasmid (Dr. Manabu Nakayama, Kazusa Institute, Japan) was transferred into DH10B cells containing the BAC clone, enabling Red/ET homologous recombination (Nakayama and Ohara, 2005). The HSV-TK-polyA cassette was PCR amplified from the GFAP-HSV-TK plasmid (Addgene pTGB008, and described in Bush et al., 1998) and inserted at the translation initiation site of the $d c x$ gene via homologous recombination. Correct clones were verified with PCR. The BAC clone contained a second gene, Calp6. To avoid transgene-mediated overexpression of Calp6, the Calp6 coding sequence was replaced with Neo cassette in reverse orientation using homologous recombination. The recombinant $\mathrm{BAC}$ was purified, and the circular BAC was injected into C57BL/ $6 \times$ DBA $(F 2)$ embryos. Ten transgenic DCX-TK founders were identified by PCR and confirmed by Southern blot. One transgenic line (line A) was used for further analysis. Copy number for line A was estimated by Southern blot to be 10 .

DCX-TK mice were backcrossed onto the C57BL/6J background. Mice used for histology studies were from N2 to N4 generations. Mice used for behavioral tests were from N3 to N6 generations. Approximately equal numbers of male and female DCX-TK and WT littermates were used in the DCX-TK experiments. Mice were housed at a maximum of five per cage under a standard $12 \mathrm{~h}$ light/dark cycle with ad libitum access to food and water. All procedures involving animals were approved by the University Committee on the Use and Care of Animals of the University of Texas at Austin.

\section{GCV administration}

GCV was administered continuously for 2 weeks via an intracerebroventricular cannula. Osmotic mini pumps (Alzet, model 1002) were filled with GCV (12.5 $\mathrm{mg} / \mathrm{ml}$ in PBS) or PBS and connected to the cannula via a vinyl catheter (Brain Infusion Kit 3; Alzet). The cannula was implanted into the lateral ventricle and delivered drug at a rate of $0.25 \mu \mathrm{l} / \mathrm{h}$. The devices were primed in saline at $37^{\circ} \mathrm{C}$ overnight before the cannula implantation.

Cannula implantation surgery was performed on 8-week-old DCX-TK transgenic mice and their WT littermates. Mice were anesthetized with isoflurane and fixed to a stereotaxic frame. An incision was made on the scalp and a small subcutaneous pocket was opened on the back of the body using a hemostat. The pump was inserted into the pocket, and the connected intracerebroventricular cannula was implanted into the lateral ventricle (tip targeted to $0.22 \mathrm{~mm}$ posterior, $1 \mathrm{~mm}$ lateral, and $2.5 \mathrm{~mm}$ ventral to bregma). The cannula and skull were covered with dental cement.

\section{BrdU administration}

BrdU was dissolved in sterile saline $(10 \mathrm{mg} / \mathrm{ml})$ and injected into mice (300 mg/kg, i.p.) twice per day for $2 \mathrm{~d}, 1$ week before mice were killed.

\section{Tissue collection and immunohistochemistry}

The mice were overdosed with a mixture of ketamine $(150 \mathrm{mg} / \mathrm{kg})$ and xylazine $(15 \mathrm{mg} / \mathrm{kg})$ and perfused with $20 \mathrm{ml}$ of PBS followed by $15-20$ $\mathrm{ml}$ of $4 \%$ PFA. Brains were postfixed overnight in $4 \%$ PFA, immersed in $30 \%$ sucrose for $2-4 \mathrm{~d}$ at $4^{\circ} \mathrm{C}$, and then flash frozen and sectioned coronally at $35 \mu \mathrm{m}$ thickness on a cryostat.

For immunofluorescence labeling, sections were incubated in blocking solution (PBS with 5\% normal donkey serum and $0.25 \%$ Triton $\mathrm{X}-100)$ for $1 \mathrm{~h}$ with gentle agitation before incubation with primary antibodies: rabbit anti-DCX (1:4000; Abcam), goat anti HSV-TK (1: 1000; Santa Cruz Biotechnology), mouse anti-NeuN (1:250; Millipore), rabbit anti-GFAP (1:2500; Dako), rat anti-BrdU (1:100; Accurate Chemical and Scientific), and rabbit anti-Ibal (1:2000; Wako). Sections were incubated with primary antibodies at room temperature overnight and rinsed for $5 \mathrm{~min}$ in three changes of PBS. Secondary antibodies (Alexa Fluor 488-conjugated donkey anti-rabbit, Cy3-conjugated donkey antigoat, and Alexa Fluor 647-conjugated donkey anti-mouse; Jackson ImmunoResearch) and DAPI (Invitrogen) were diluted in PBS (secondary antibodies at 1:250; DAPI at $300 \mathrm{~nm}$ ) with 5\% normal donkey serum and $0.25 \%$ Triton $\mathrm{X}-100$. Sections were incubated for $2 \mathrm{~h}$ at room temperature with gentle agitation, and then rinsed in PBS, mounted, and coverslipped.

For BrdU immunohistochemistry, DNA denaturation was performed before application of the primary antibody using a procedure modified from Leuner et al. (2009). Floating sections were incubated in $2 \mathrm{~N}$ hydrochloric acid for $30 \mathrm{~min}$ at room temperature and then neutralized in 0.1 
$\mathrm{M}$ boric acid, $\mathrm{pH} 8.5$, for $10 \mathrm{~min}$. Sections were rinsed in PBS twice for 5 min each before application of primary antibodies, as described above.

\section{Cell quantification}

Labeled cells were counted in every 12th section throughout the dentate gyrus (DG; six sections in total) by an experimenter blind to experimental condition. BrdU + cells were counted exhaustively under fluorescent illumination (Zeiss Axio Imager M2) using a $20 \times$ objective (PlanNeofluar 0.5 NA). All BrdU+ cells located in the GCL or the subgranular zone (SGZ) were counted. DCX cells in the SGZ were quantified using an optical fractionator (Stereo Investigator; MBF Bioscience). Counting was performed using a $40 \times$ objective (Plan-Neofluar $0.75 \mathrm{NA}$ ), counting frame of $60 \times 60 \mu \mathrm{m}$, sampling grids of $360 \times 100 \mu \mathrm{m}$, and $1 \mu \mathrm{m}$ guard zones. At least 166 cells were counted per WT mouse. Cell counts are reported separately for the anterior and posterior DG. Anterior was defined as approximately -0.94 to $-2.54 \mathrm{~mm}$ relative to bregma and comprised sections 1-4 of the six-section series (Paxinos, 2001). Posterior DG was defined as -2.70 to $-3.40 \mathrm{~mm}$ and comprised sections $5-6$ of the six-section series. Iba-1 cells in the DG were also quantified using the optical fractionator. Counting was performed using a $40 \times$ objective (Plan-Neofluar $0.75 \mathrm{NA}$ ), counting frame of $100 \times 100 \mu \mathrm{m}$, sampling grids of $350 \times 200 \mu \mathrm{m}$, and $1 \mu \mathrm{m}$ guard zones. At least 174 cells were counted per mouse.

To assess colocalization of BrdU/NeuN and BrdU/GFAP, $20 \mathrm{BrdU}+$ cells were imaged per mouse. $Z$-stacks were collected for each cell using a $63 \times$ oil-immersion objective (Plan-Apochromat $1.4 \mathrm{NA}$ ) and a Zeiss ApoTome structured illumination module. The total number of doublelabeled cells was estimated for each mouse by multiplying the proportion of double-labeled BrdU + cells (in the 20 cell analysis) by the total number of BrdU+ cells (counted as described above).

\section{$X$-ray irradiation}

$\mathrm{X}$-irradiation was performed as described previously (Santarelli et al., 2003; David et al., 2009; Denny et al., 2012). Male mice were anesthetized with sodium pentobarbital $(6 \mathrm{mg} / \mathrm{kg})$, placed in a stereotaxic frame, and exposed to cranial irradiation using a Siemens Stabilopan x-ray system operated at $300 \mathrm{kVp}$ and $20 \mathrm{~mA}$. Mice were protected with a lead shield that covered the entire body, but left unshielded a $3.22 \times 11 \mathrm{~mm}$ treatment field above the hippocampus (interaural 3.00 to 0.00 ). The dose rate was $\sim 1.8 \mathrm{~Gy} / \mathrm{min}$ at a source to skin distance of $30 \mathrm{~cm}$. Three $5 \mathrm{~Gy}$ doses were administered over $8 \mathrm{~d}$.

\section{Open field test}

The mouse was placed in a $40 \times 40 \mathrm{~cm}$ arena for $30 \mathrm{~min}$. The walls were $35 \mathrm{~cm}$ high of opaque plastic. A light bulb mounted above provided 85 lux illumination, measured in the center of the arena. Sessions were recorded via a digital camera, and videos were analyzed off-line using video-tracking software (ANY-Maze; Stoelting). The center was defined as an $18.5 \times 18.5 \mathrm{~cm}$ zone in the center of the arena.

\section{Elevated plus maze}

The mouse was placed in the center of the plus-shaped maze for $5 \mathrm{~min}$. Each arm was $30 \mathrm{~cm}$ in length and $5 \mathrm{~cm}$ in width. Two were "closed" arms with walls $13 \mathrm{~cm}$ in height while the other two were "open" arms. Light bulbs mounted above the apparatus provided a 55 lux illumination on the open arms. The maze was on a stand, $\sim 130 \mathrm{~cm}$ above the floor. Traveled time and distance in each arm and center zone were analyzed off-line using video-tracking software (ANY-Maze; Stoelting). The maze was cleaned with $70 \%$ ethanol after each run.

\section{Fear conditioning}

Fear conditioning took place in Med Associates conditioning chambers (30 $\mathrm{cm}$ wide $\times 24 \mathrm{~cm}$ deep $\times 22 \mathrm{~cm}$ high). The chambers could be configured as two distinct contexts, A and B. Context A was rectangular, had floors made of stainless steel rods $(2 \mathrm{~mm}$ diameter, spaced $5 \mathrm{~mm}$ apart), had walls of aluminum and acrylic, was scented with acetic acid, and was cleaned with $70 \%$ ethanol between runs. Context B had a white acrylic floor, had an acrylic A-frame roof, and was cleaned with antiseptic wipes (Clorox Fresh Scent). The training session and context test occurred in context A. The tone test occurred in context $\mathrm{B}$. All sessions were recorded from the side using a digital camera. Freezing behavior was scored using a pixel-change algorithm (Video Freeze; Med Associates).

Protocol 1A (DCX-TK experiments). Training consisted of four conditioning trials during a $440 \mathrm{~s}$ session in context A (Figs. 5-7, 9). The conditioned stimulus was a tone $(85 \mathrm{~dB}, 5000 \mathrm{~Hz})$. The unconditioned stimulus was footshock ( $2 \mathrm{~s}, 0.8 \mathrm{~mA})$. The tone was presented at 120, 200, 270 , and $360 \mathrm{~s}$ into the session. In delay conditioning, the footshock occurred at tone offset. In trace conditioning, the footshock commenced $20 \mathrm{~s}$ after tone offset. In "foreground" contextual conditioning, footshock was presented at 160,240,310, and $400 \mathrm{~s}$ into the session, and the tone was not presented.

On the day following training, the mouse was returned to context A for $5 \mathrm{~min}$ for a test of context-elicited fear. Neither tones nor shocks were presented. Freezing behavior was scored throughout the session. On the third (trace and shock-alone conditioning) or fourth (delay conditioning) day, the mouse was placed into context $\mathrm{B}$ for a test of tone-elicited fear. The tone was presented four times for $20 \mathrm{~s}$ each at 120,200,270, and $360 \mathrm{~s}$ into the session. Delay fear-conditioned mice received a test session in context B to a novel auditory stimulus, a white noise, on the third day.

Protocol 1B (X-irradiation experiments). Context A was as described above (Fig. 8). Context B was created by covering the walls with curved plastic inserts and covering the floor with bedding material. Context $\mathrm{B}$ was scented with lemon extract and cleaned with nonalcohol disinfectant wipes. On the day before training, mice received $3 \mathrm{~min}$ pre-exposures to context A and B. Training consisted of five pairings between a $20 \mathrm{~s}$ tone $(85 \mathrm{~dB}, 2000 \mathrm{~Hz})$ and a footshock $(2 \mathrm{~s}, 0.65 \mathrm{~mA})$ in context A. The tones were presented at $190,465,690,990$, and $1190 \mathrm{~s}$ into the session. The shocks occurred at tone offset (delay conditioning) or $20 \mathrm{~s}$ after tone offset (trace conditioning). The test of tone-elicited fear occurred in context B on the day after training. The tone was presented for $20 \mathrm{~s}$ each at 190 and $330 \mathrm{~s}$ into the session. The context test occurred on the following day. Mice were placed in context A for $5 \mathrm{~min}$ with no tones or shocks presented.

Protocol 2 (DCX-TK experiments). Mice were handled for 2 min per day for $5 \mathrm{~d}$ before conditioning (Fig. 12). Training occurred in Context $\mathrm{A}$ and consisted of five tone-shock pairings during a $1280 \mathrm{~s}$ session. In trace conditioning, the tone $(20 \mathrm{~s}, 75 \mathrm{~dB})$ was presented at 180, 370, 620, 900, and $1060 \mathrm{~s}$ into the session. The shock $(0.5 \mathrm{~mA}, 2 \mathrm{~s})$ occurred $20 \mathrm{~s}$ after tone offset. In foreground context conditioning, the shock occurred at $220,410,660,940$, and $1100 \mathrm{~s}$ into the session, and the tone was not presented. For unpaired training, the tone $(20 \mathrm{~s}, 75 \mathrm{~dB})$ was presented at $180,370,620,900$, and 1060 s into the session, and the shock occurred at $120,300,500,820$, and $1160 \mathrm{~s}$ into the session.

The test for context-elicited fear occurred on the following day and consisted of a $5 \mathrm{~min}$ exposure to context A. Neither the tone nor shock was presented. The test for tone-elicited fear occurred in context $\mathrm{B}$ on the following day. The tone was presented for $20 \mathrm{~s}$ at $180,280,390,510$, and $620 \mathrm{~s}$ into the session.

\section{Shock reactivity}

The unconditioned response to footshock was assessed by estimating horizontal distance traveled during the shock and by quantifying the frequency of four behaviors commonly exhibited during footshock: running, jumping, backward shuffling, and forward shuffling. Shuffling was defined as locomotion without full limb extension. Horizontal distance was estimated by quantifying crossings of a four-cell grid superimposed over the conditioning chamber.

\section{Statistical analysis}

Cell counts and body weights were analyzed with Prism6 (GraphPad) using Student's $t$ test for two-condition analyses and one-way ANOVA for analyses including more than two conditions. Tukey's test was used for post hoc pairwise comparisons. Body weight data were analyzed with repeated-measures ANOVA (RM-ANOVA).

Behavioral data were analyzed with JMP11 Pro (SAS institute). Student's $t$ test and one-way or two-way ANOVAs were used to analyze between-subjects designs. Repeated-measures designs were analyzed using the mixed-effects restricted maximum likelihood (REML) model. The null hypothesis was rejected at the $p<0.05$ level. 
A

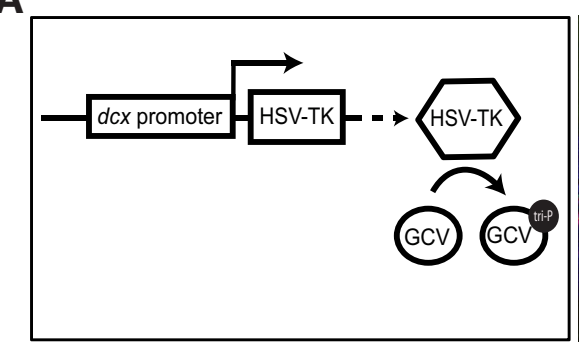

B

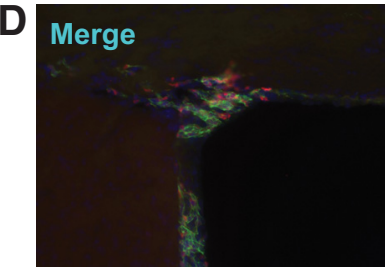

E

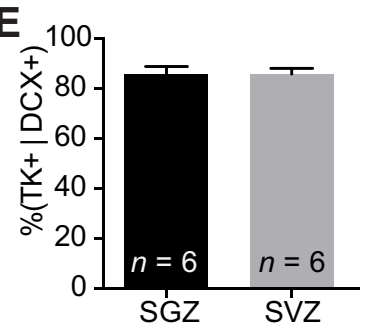

Nuclei

F
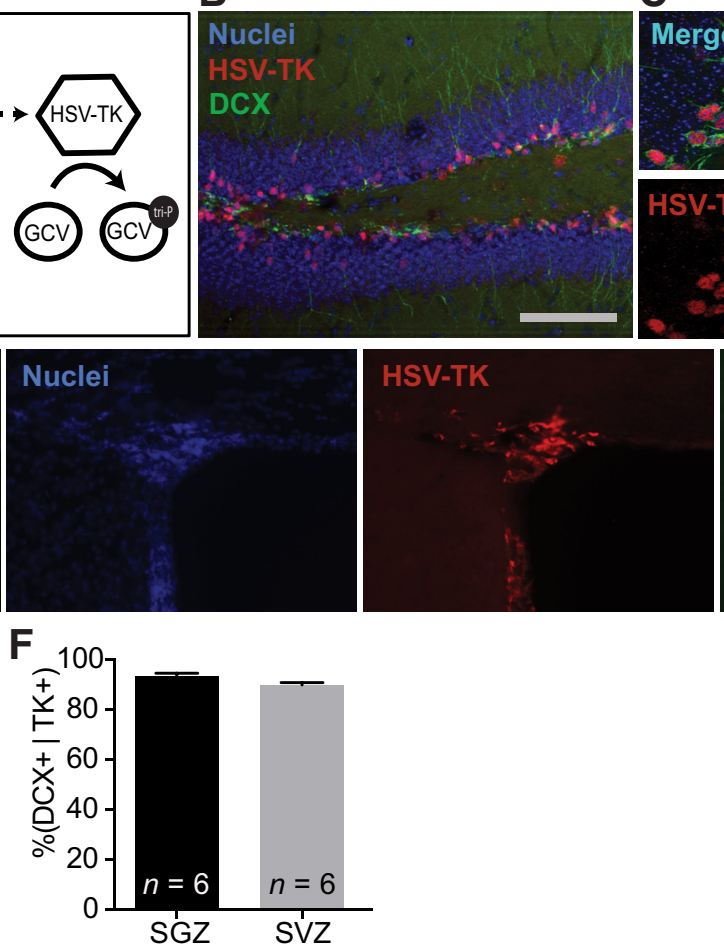

C
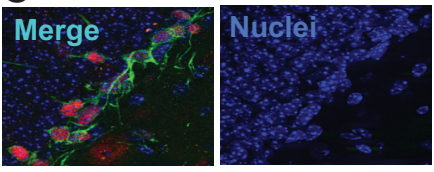

DCX

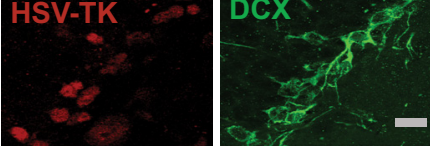

$\mathrm{DCX}$

HSV-TK

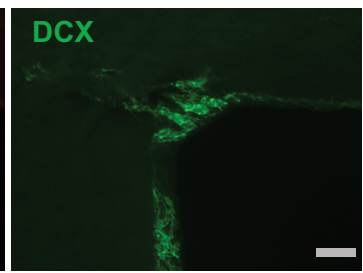

Figure 1. HSV-TK expression in DCX-TK transgenic mice. $A$, Transgenic mice express HSV-TK under control of the $d c x$ gene promoter. HSV-TK catalyzes the formation of GCV-triphosphate (tri-P), which prevents DNA replication and kills dividing cells. $\boldsymbol{B}-\boldsymbol{D}, \mathrm{DCX}$-TK mice expressed HSV-TK in DCX + cells in the $D G(\boldsymbol{B}, \boldsymbol{C})$ and around the lateral ventricle (D). $\boldsymbol{E}$, Percentage of DCX+ cells expressing HSV-TK in the SGZ and SVZ. F, Percentage of HSV-TK + cells expressing DCX. Scale bars: $\boldsymbol{B}, \boldsymbol{D}, 100 \mu \mathrm{m} ; \boldsymbol{C}, 10 \mu \mathrm{m}$.

\section{Results}

Generation and characterization of DCX-TK transgenic mice We generated transgenic mice that express HSV-TK under the DCX promoter. HSV-TK catalyzes the conversion of a prodrug, GCV, into a toxic intermediate that terminates DNA synthesis, killing diving cells (Fig. 1A; Beltinger et al., 1999). Thus, administration of GCV to DCX-TK transgenic mice suppresses hippocampal neurogenesis, while leaving the production of other cell types intact.

Ten transgenic DCX-TK founders were obtained and confirmed using Southern blot. Of these four were fertile. One line, line A, was maintained and used for further analysis. The mice appeared healthy and exhibited normal growth. In DCX-TK mice, TK + cells were abundant in the SGZ (Fig. $1 B, C$ ) and SVZ (Fig. $1 D$ ). In both regions, HSV-TKexpression was largely confined to DCX + cells. The percentage of DCX + cells expressing HSV-TK was $>80 \%$ (Fig. 1E), and the percentage of HSV-TK cells expressing DCX was $>90 \%$ (Fig. 1F). Consistent with evidence that DCX is expressed at low levels outside of these canonical neurogenic niches, sparse HSV-TK expression was also observed in other cortical regions (see below).

To characterize the ablation efficiency and specificity, we treated the DCX-TK and WT mice with GCV or PBS for 2 weeks via intracerebroventricular infusion. The mice were injected with BrdU 1 week before being killed (Fig. 2A). Body mass increased over time during GCV administration and was not affected by genotype or drug (Fig. 2B; RM-ANOVA: Group, $F_{(2,11)}=0.69, p=0.52$; Time, $F_{(2,22)}=14.59, p<$ 0.001 ; Group $\times$ Time, $\left.F_{(4,22)}=0.70, p=0.60\right)$. To assess the effect of the treatments on neurogenesis, we quantified DCX+ cells in the SGZ. The number of DCX + cells was greatly re- duced $(80-85 \%)$ in the anterior DG of DCX-TK/GCV mice as compared with the DCX-TK/PBS and WT/GCV groups (Fig. $2 C, G ; F_{(2,11)}=76.29, p<0.001$; Tukey: DCX-TK/GCV vs $\mathrm{WT} / \mathrm{GCV}$ or DCX-TK/PBS, $p<0.001)$. The control groups (WT/GCV or DCX-TK/PBS) did not differ from each other $(p=0.26)$. In posterior DG, the reduction of DCX + cells in DCX-TK/GCV mice was somewhat smaller $(60-65 \%)$ than that seen in the anterior GCL. Nevertheless, the reduction was significant (Fig. $2 D, H ; F_{(2,11)}=9.07, p=0.005$; Tukey: DCXTK/GCV vs WT/GCV or DCX-TK/PBS, $p<0.001)$.

Next, we sought to determine whether HSV-TK-expressing cells in non-neurogenic regions had been ablated by GCV administration. Consistent with evidence for DCX expression in neurons of the piriform cortex, DCX +/HSV-TK + double-labeled cells were found in layer II of piriform cortex (Fig. 2E,F). In contrast to DCX + cells in the SGZ, these cells are not proliferative (Klempin et al., 2011) and, thus, should not be ablated by GCV treatment. Consistent with this hypothesis, the density of TK + cells in piriform cortex did not differ between DCX-TK/GCV and DCX-TK/PBS mice (Fig. $2 I ; t_{(7)}=0.12, p=0.430$ ).

We confirmed that the reduction in DCX + cells in DCXTK/GCV mice reflected a suppression of neurogenesis by quantifying BrdU + cells. The number of BrdU+ cells was greatly reduced in the GCL of DCX-TK/GCV mice as compared with controls (Fig. $3 A$ ). In the anterior DG, the number of BrdU + cells was reduced by $\sim 80 \%$ in DCX-TK mice as compared with controls (Fig. $3 C$; one-way ANOVA: $F_{(2,11)}=$ $11.82, p=0.002$; Tukey: DCX-TK/GCV vs WT/GCV or DCXTK/PBS, $p<0.01$ ) and, in posterior DG, there was $\sim 70 \%$ reduction (Fig. $3 C$; one-way ANOVA: $F_{(2,11)}=9.50, p=$ 0.004; Tukey: DCX-TK/GCV vs WT/GCV, $p<0.01$; DCX-TK/ GCV vs DCX-TK/PBS, $p<0.05)$. The number of BrdU + cells 

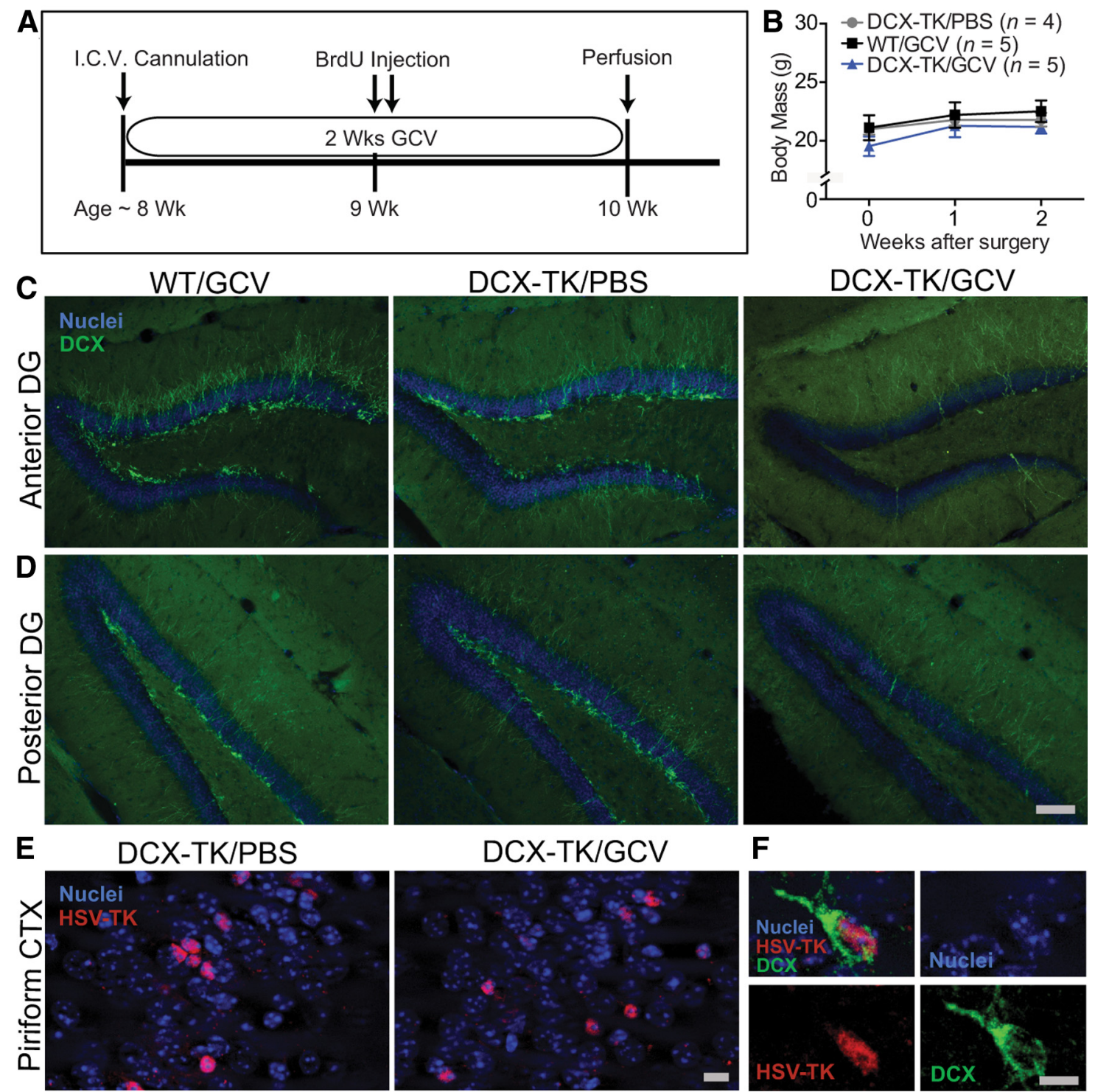

\section{$\mathbf{F}$}

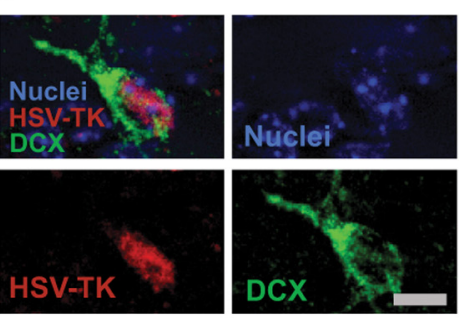

G
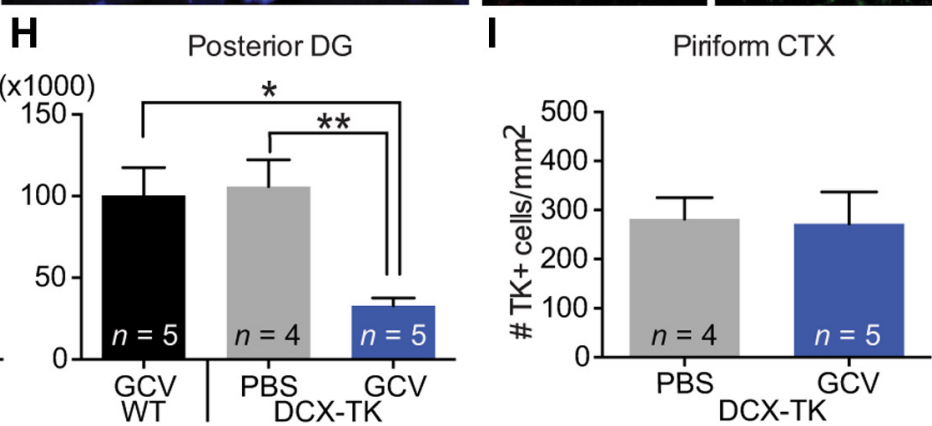

Figure 2. GCV administration to $D C X$-TK transgenic mice depletes $D C X+$ immature neurons in the $D G$ but does not deplete putative quiescent $D C X+$ cells in the piriform cortex. $A, D C X$-TK and WT mice were treated with GCV or vehicle (PBS) for 2 weeks. Mice were injected with BrdU and killed 1 week later. $B$, Body mass during the 2 weeks of GCV administration did not differ among DCX-TK/GCV, DCX-TK/PBS, and WT/GCV mice. C, D, Representative images of DCX immunohistochemistry in the DG. $\boldsymbol{E}$, Immunohistochemistry against HSV-TK in the piriform cortex of DCX-TK transgenic mice. $\boldsymbol{F}$, Representative image of an HSV-TK + /DCX + double-labeled cell in the piriform cortex. Most HSV-TK + cells in the piriform cortex also expressed DCX. $\boldsymbol{G}, \boldsymbol{H}$, The number of DCX+ cells in anterior and posterior DG was greatly reduced in DCX-TK/GCV mice relative to controls. $\boldsymbol{E}, I, I$ In contrast, HSV-TK + cells in the piriform cortex were not ablated by GCV treatment in DCX-TK mice. Scale bars: $C, D, 100 \mu \mathrm{m} ; \boldsymbol{E}, \boldsymbol{F}, 10 \mu \mathrm{m} .{ }^{*} p<0.05,{ }^{* *} p<0.01,{ }^{* * *} p<0.001$. CTX, cortex; I.C.V., intracerebroventricular.

was also greatly reduced in the SVZ of DCX-TK/GCV mice as compared with controls (data not shown).

Next, we examined ablation specificity in the DG by assessing colocalization of BrdU with markers of neuronal (NeuN) and glial (GFAP) identity (Fig. 3B). Because DCX is expressed in neuronal-committed progenitor cells, but not in multipotent stem-like cells (Brown et al., 2003; Kempermann et al., 2004; Wang et al., 2005), we predicted that GCV administration to DCX-TK mice would arrest neurogenesis but not gliogenesis. Consistent with this prediction, the number of $\mathrm{BrdU}+/ \mathrm{NeuN}+$ 
A

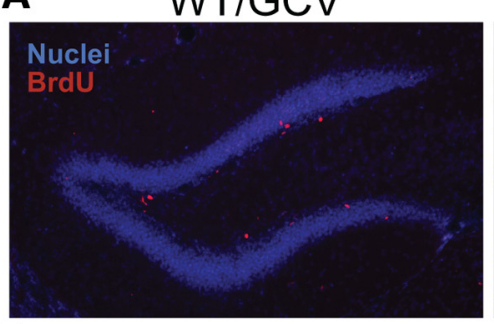

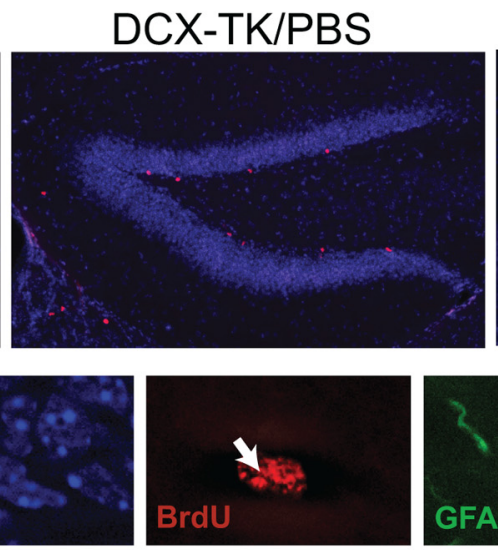
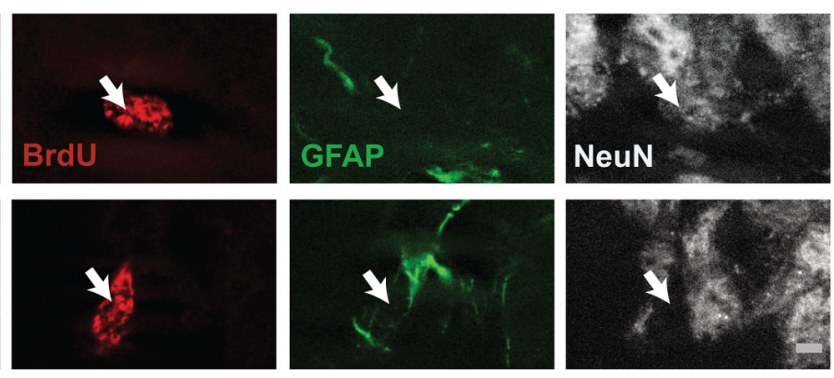

D
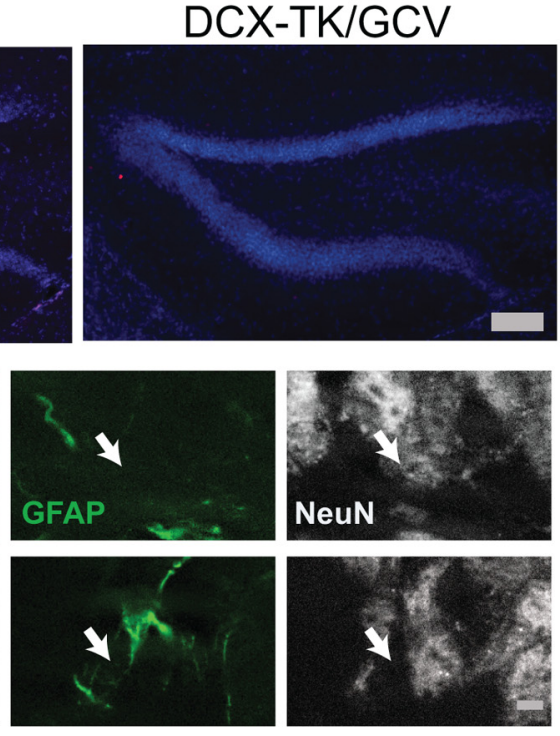

E

B
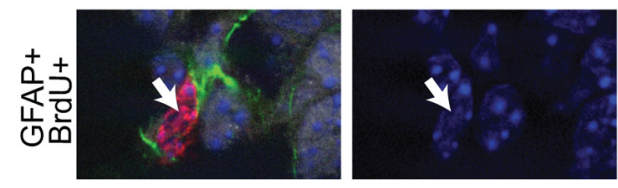

C
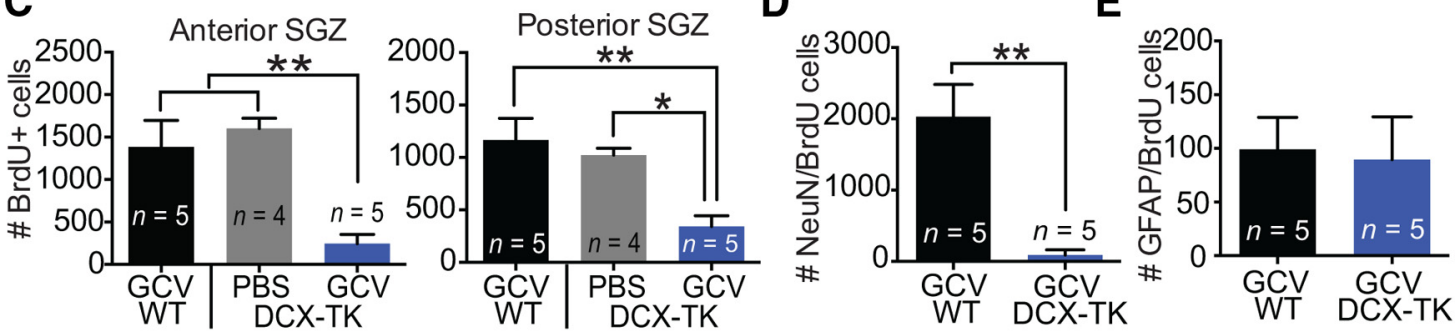

Figure 3. GCV administration to DCX-TK mice suppresses DG neurogenesis but not gliogenesis. $A$, Representative images of BrdU immunohistochemistry in the DG. $\boldsymbol{B}$, Examples of BrdU + cells colabeled with NeuN or GFAP. C, In both anterior and posterior DG, the number of BrdU + cells was greatly reduced in DCX-TK/GCV mice relative to controls $D, E$, Quantification of BrdU/GFAP and BrdU/NeuN double-labeled cells. The proportion of BrdU + cells expressing NeuN was reduced in DCX-TK/GCV mice relative to WT/GCV controls (D). However, the proportion of BrdU + cells expressing GFAP did not differ between DCX-TK/GCV and WT/GCV mice (E). Scale bars: $\boldsymbol{A}, 100 \mu \mathrm{m} ; \boldsymbol{B}, 5 \mu \mathrm{m}$. ${ }^{*} p<0.05,{ }^{* *} p<0.01$.

adult-born neurons was greatly reduced in DCX-TK/GCV mice as compared with controls (Fig. $3 D ; t_{(8)}=4.23, p=0.004$ ), but the number of BrdU+/GFAP+ newborn glia did not differ among groups (Fig. $3 E ; t_{(8)}=0.19, p=0.596$ ). This result suggests that the DCX-TK/GCV system specifically arrests adult neurogenesis.

To determine whether GCV treatment to DCX-TK mice evoked an inflammatory response, we performed immunohistochemistry against Iba-1, a marker of microglia upregulated with microglial activation associated with inflammation (Ito et al., 2001). Animals were treated with either GCV or PBS for 2 weeks (Group: WT/GCV, DCX-TK/PBS, or DCX-TK/GCV) and then killed immediately (WT/GCV, $n=5$; DCX-TK/PBS, $n=4$; DCX-TK/GCV, $n=5)$ or 2 weeks ( $n=3$ in each group) after the end of drug treatment. Iba-1 expression intensity was measured in DG. No significant effects of Group or interaction were detected (two-way ANOVA: Group, $F_{(2,17)}=2.05, p=$ 0.160 ; Group $\times$ Recovery Interval, $\left.F_{(2,17)}=0.14, p=0.870\right)$. However, the main effect of Recovery Interval was significant $\left(F_{(1,17)}=82.24, p<0.001\right)$, indicating that the microglial activation declines over time after surgery. We further analyzed DG inflammatory markers 1 week after the end of GCV treatment, which correspond to the time of behavioral testing (WT/GCV $n=4$; DCX-TK/GCV $n=4$ ). There were no significant differences between genotypes in Iba-1 intensity (Fig. $\left.4 A, C ; t_{(6)}=1.12, p=0.306\right)$ or the number of Iba- $1+$ cells (Fig. $4 D ; t_{(6)}=0.49, p=0.638$ ). We also measured GFAP immunoreactivity as a marker of astrogliosis and astroglial activation (Brahmachari et al., 2006). GFAP fluorescence intensity did not differ between genotypes (Fig. $4 B, E ; t_{(6)}=0.28$, $p=0.791)$. These results suggest microglial activation was induced by surgery, not by GCV treatment or genotype per se.

Effect of DCX-TK-mediated arrest of neurogenesis on delay and trace fear conditioning

We predicted that arrest of adult neurogenesis would impair hippocampus-dependent trace fear conditioning but have no effect on delay fear conditioning, which typically does not require hippocampal integrity. Delay and trace fear conditioning were assessed in separate groups of WT and DCX-TK mice treated with GCV (Fig. 5A). Fear conditioning occurred 1 week after the end of 2 weeks of GCV treatment. Mice received four pairings between a tone and shock using a delay (shock occurred at tone offset) or trace (shock occurred $20 \mathrm{~s}$ after tone offset) protocol.

On the training day (Day 1), freezing levels were measured in $10 \mathrm{~s}$ bins across the entire session. All groups reached $\sim 80 \%$ freezing after the last training trial. The freezing levels in time bins were analyzed using REML. During delay training, freezing levels increased more rapidly in WT/GCV than in DCX-TK/GCV mice (Fig. $5 B$; Genotype $\times$ Time, $F_{(43,1075)}=1.82, p=0.001$ ). The opposite pattern was observed in trace training (Fig. $5 C$; Genotype $\times$ Time, $\left.F_{(43,1161)}=2.09, p<0.001\right)$. However, freezing levels after the final shock were equivalent between the two genotypes in both trace $\left(t_{(27)}=-1.89, p=0.07\right)$ and delay $\left(t_{(25)}=\right.$ $-0.56, p=0.58)$ conditioning. 
On the next day, mice were placed into the training context for a test of contextelicited fear. Consistent with our previous data (Clark et al., 2008; Drew et al., 2010), in delay conditioning there was no effect of genotype on the level of contextelicited freezing (Fig. 5D; Genotype, $F_{(1,25)}$ $=0.01)$. After trace conditioning, however, DCX-TK/GCV mice froze significantly more than WT/GCV mice throughout the context test (Fig. 5E; $\left.F_{(1,27)}=7.10, p=0.013\right)$.

On the third day, mice were placed into a novel context for a test of toneelicited fear. Freezing was compared during the baseline period (20 s before the first tone) to the mean freezing during the CS and the post-CS periods (20 s after tone-off). These data were analyzed using Period (Baseline, CS, and Post-CS) $\times$ Genotype REML. Based on evidence that the hippocampus controls fear generalization in auditory fear conditioning (Quinn et al., 2009; Cushman et al., 2012), delaytrained mice were tested for freezing in response to a novel auditory stimulus, a white noise, in addition to the original tone stimulus. Both genotypes displayed freezing to the tone and white noise (Fig. $5 F, H$; white noise data not shown), and there was no effect of genotype on freezing to either the white noise (WN; Genotype, $F_{(1,25)}=0.68, p=0.417$; Period, $F_{(2,50)}=$ 65.90, $p<0.001$; Tukey: Baseline vs WN or Post-WN, $p<0.001$; WN vs Post-WN, $p=0.949$ ) or the tone (Genotype, $F_{(1,25)}$ $=0.46, p=0.504$; Period, $F_{(2,50)}=38.75$, $p<0.001$; Tukey: Baseline vs CS or PostCS, $p<0.001$; CS vs Post-CS, $p=0.014$ ).

Trace-conditioned mice also exhibited freezing in response to the tone (Fig. $5 G, I$ ), and there was no effect of genotype during the baseline, CS, or post-CS periods (Genotype, $F_{(1,27)}=2.36, p=0.137$; Period, $F_{(2,54)}=40.94, p<$ 0.001 ; Tukey: Baseline vs CS or Post-CS, $p<0.001$; CS vs PostCS, $p=0.851)$. However, when the entire baseline period was analyzed ( 2 min before the first CS presentation), DCX-TK/GCV mice froze significantly more than WT/GCV mice $\left(t_{(27)}=-3.59\right.$, $p<0.01)$.

To determine whether the increased context-elicited freezing in trace-trained DCX-TK/GCV mice related to a change in shock sensitivity, we assessed the behavioral response to shock during trace training. Figure $6 A$ shows general activity (number of grid crossings) during each of the four shock presentations during the training. The number of grid crossings did not differ by genotype (two-way ANOVA: Genotype, $F_{(1,27)}=0.96, p=0.943$; Trial, $F_{(3,81)}=5.25, p=0.002$; Genotype $\times$ Trial interaction, $F_{(3,81)}=$ $0.39, p=0.760)$. We also quantified the frequency of four behaviors commonly displayed during shock across the four-trial session (running, jumping, shuffling, and backward shuffling). There was no effect of genotype on the relative frequency of each behavior (Fig. 6B; two-way ANOVA: Genotype, $F_{(1,108)}=0.49$, $p=0.488$; Genotype $\times$ Trial interaction, $F_{(3,108)}=0.33, p=$ $0.807)$.
To confirm that the increased fear in trace-conditioned DCX-TK mice was caused by neurogenesis ablation rather than an extraneous effect of the transgene (e.g., a site-ofintegration effect), PBS-treated DCX-TK and WT mice were subjected to trace fear conditioning using the procedure described above.

In the training session there was no effect of Genotype or of the Genotype $\times$ Time interaction (Fig. 7A; REML: Genotype, $F_{(1,30)}=0.85, p=0.365$; Genotype $\times$ Time, $F_{(43,1290)}=0.82, p=$ $0.796)$. On the day following training, contextual fear was assessed in the training context. There were no effects of Genotype or the Genotype $\times$ Time interaction (Fig. 7B; REML: Genotype, $F_{(1,30)}=0.12, p=0.73$; Genotype $\times$ Time, $F_{(3,90)}=1.10, p=$ $0.355)$. On the third day, tone fear was assessed in a novel context. Both groups displayed freezing in response to the tone, and there was no effect of Genotype or the Genotype $\times$ Period (Baseline, CS, and Post-CS) interaction (Fig. 7C,D; REML: Genotype, $F_{(1,30)}$ $=1.27, p=0.269$; Period, $F_{(2,60)}=61.20, p<0.001$; Genotype $\times$ Period, $F_{(2,60)}=0.06, p=0.942$; Tukey: Baseline vs CS, $p<0.001$; Baseline vs CS, $p=0.01$; Baseline vs Post-CS, $p<0.001$; CS vs Post-CS, $p<0.001)$.

In summary, arrest of adult neurogenesis was associated with enhanced context fear in trace but not delay conditioning. The 
A

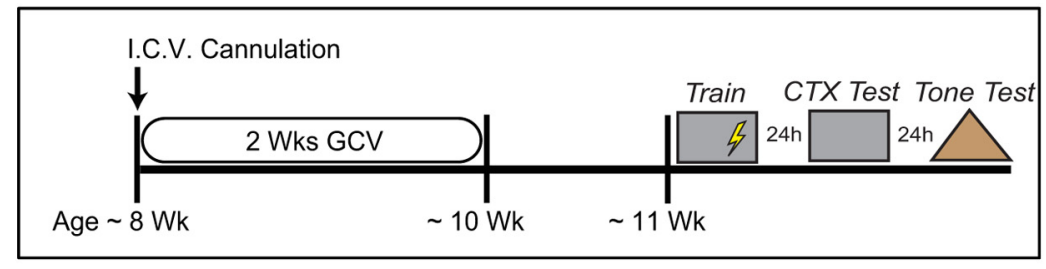

Delay $-W T / G C V(n=12)$

Trace $-\mathrm{WT} / \mathrm{GCV}(n=16)$

DCX-TK/GCV $(n=15)$
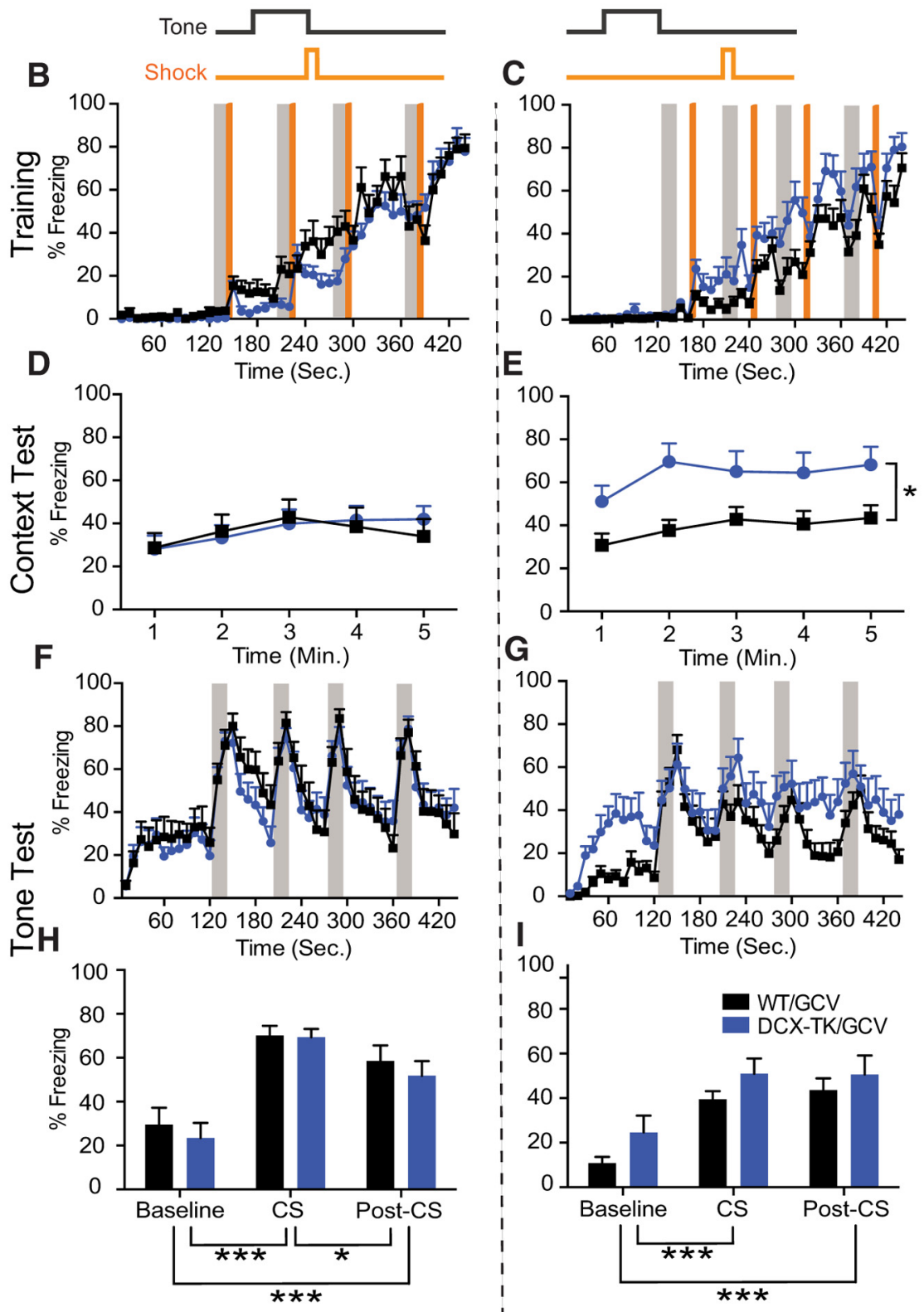

Figure 5. Effects of DCX-TK-mediated arrest of adult neurogenesis on trace and delay fear conditioning. $A, D C X$-TK and WT mice were trained in delay or trace fear conditioning 1 week after a 2 week GCV treatment. B, During delay training, WT mice displayed a more rapid acquisition of freezing behavior than DCX-TK mice. $C$, In contrast, during trace training DCX-TK mice displayed a more rapid acquisition of freezing behavior. However, freezing levels in the final minute of the training session (after the final shock) were equivalent between the two genotypes in both Delay and Trace conditioning. $\boldsymbol{D}, \boldsymbol{E}$, Freezing during the context test. In trace (E) but not delay (D) conditioning, DCX-TK/GCV mice displayed significantly higher freezing than WT/GCV mice. $\boldsymbol{F}$-I, Freezing in response to the tone $C S$ in a novel context. $\boldsymbol{H}, \boldsymbol{I}$, Mean freezing during the baseline ( $20 \mathrm{~s}$ before tone presentation), during tone presentation, and during the $20 \mathrm{~s}$ after tone presentation. In delay conditioning $(\boldsymbol{H}), \mathrm{WT} / \mathrm{GCV}$ and DCX-TK/GCV displayed freezing in response to the tone, and there was no effect of genotype on freezing. Similarly, in trace conditioning $(I)$, mice displayed freezing in response to the tone, and there was no genotype effect. ${ }^{*} p<0.05$, ${ }^{* * *} p<0.001$. I.C.V., intracerebroventricular. enhancement was not caused by increased shock sensitivity or by a nonspecific effect of the DCX-TK transgene.

Effect of targeted cranial irradiation on delay and trace fear conditioning

To confirm that the unexpected phenotype in trace fear conditioning was caused by the arrest of adult hippocampal neurogenesis rather than another effect of the ablation system, we assessed trace and delay fear conditioning using an alternate neurogenesis ablation method. Fear conditioning was conducted 6 weeks after hippocampus-targeted $\mathrm{x}$-irradiation (Fig. $8 A)$. We confirmed that the $\mathrm{x}$-irradiation greatly reduced the number of DCX+ cells in the SGZ (Fig. 8B,C) compared with the sham-irradiated mice in both the anterior $\left(t_{(6)}=4.41, p<0.01\right)$ and posterior $\mathrm{DG}\left(t_{(6)}=4.17, p<0.01\right)$.

Mice received five pairings between a tone and shock using a delay or 20 s trace protocol. In the tone test session (Fig. $8 D, E)$, we compared freezing during the baseline period to the mean freezing during the CS and the post-CS periods. These data were analyzed using a Period (Baseline, CS, and Post-CS) $\times$ Treatment ANOVA. In each protocol there was a significant effect of Period $\left(F_{(2,36)}>12\right.$, ps $<0.001$ ), confirming that freezing during the CS and Post-CS periods exceeded that during the Baseline period. The effects of Treatment $\left(F_{(1,18)}<1\right)$ and the interaction $\left(F s_{(2,36)}<2.25\right.$, ps $\left.>0.12\right)$ were not significant. Arrest of neurogenesis via $\mathrm{x}$-irradiation failed to impair trace fear conditioning.

Consistent with the DCX-TK experiments, in the context test session, there was an effect of neurogenesis ablation in the trace protocol but not the delay protocol (Fig. $8 F$ ). In delay conditioning there was no effect of $\mathrm{x}$-irradiation on context-elicited freezing. A Time $\times$ Treatment ANOVA confirmed no effect of Treatment $\left(F_{(1,18)}<\right.$ 1) or of the interaction $\left(F_{(3,54)}=1.4, p=\right.$ 0.26 ). In trace conditioning, however, $\mathrm{x}$-irradiated mice displayed significantly stronger context-elicited freezing (Main effect of Treatment: $\left.F_{(1,18)}=5.2, p=0.035\right)$. Thus, ablation of adult neurogenesis by either DCX-TK/GCV or $\mathrm{x}$-irradiation caused enhanced context fear in trace but not delay fear conditioning.

\section{Evidence for nonassociative freezing after fear conditioning}

The increased contextual fear in mice lacking neurogenesis is puzzling but may reflect an impaired ability to associate the tone with shock. Various models of classical condi- 

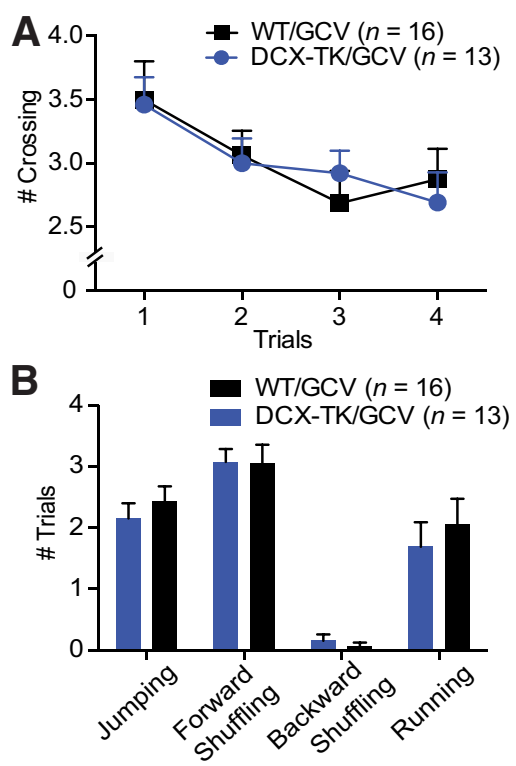

Figure 6. Shock reactivity during trace fear conditioning. $A$, The number of crossings of the conditioning chamber did not differ between genotypes. $\boldsymbol{B}$, The two genotypes showed similar behaviors during the shock-induced activity burst.

tioning assume that stimuli compete for a limited supply of associative strength, with better predictors acquiring associative strength at the expense of weaker predictors (Urushihara and Miller, 2009; Urcelay and Miller, 2014). In tone fear conditioning, the tone and context compete for associative strength. As a result, manipulations that impair the ability to form an association between tone and shock may cause a compensatory increase in the strength of the context-US association (Marlin, 1981). We asked whether the increased context fear in mice lacking neurogenesis reflects an impaired ability to associate the tone with shock in trace conditioning.

Before addressing this question, it was necessary to determine the extent to which tone-elicited freezing reflects a tone-shock association. In addition to producing associative fear of a trained CS, fear conditioning can cause nonassociative emotional changes, such as generalized fear and anxiety-like behavior expressed even in the absence of conditioned stimuli. For example, exposure to footshock can cause mice to display freezing responses to a tone that was never paired with shock (Kamprath and Wotjak, 2004). We sought to determine whether our trace-conditioning procedure induced nonassociative behavioral phenotypes. Experimentally naive groups of DCX-TK and WT mice were treated with GCV for 2 weeks. One week after the conclusion of GCV, mice received "foreground" contextual fear conditioning, in which the footshocks were presented alone without being preceded by a tone. The conditioning parameters (e.g., number, intensity, and timing of the shocks) were otherwise identical to those in the DCX-TK trace fear-conditioning procedure described above.

For the training session, we assessed freezing behavior in $10 \mathrm{~s}$ bins across the entire session. There were no effects of Genotype or of the Genotype $\times$ Time interaction (Fig. 9A, REML: Genotype, $F_{(1,57)}=1.04, p=0.313$; Genotype $\times$ Time, $F_{(43,2451)}=$ $0.84, p=0.760)$. On the day following training, mice were placed into the training context to test for contextual fear. There were no significant effects of Genotype or the Genotype $\times$ Time interaction (Fig. 9B; REML: Genotype, $F_{(1,57)}=1.04, p=0.364$; Genotype $\times$ Time, $\left.F_{(4,228)}=0.08, p=0.988\right)$. On the third day, mice
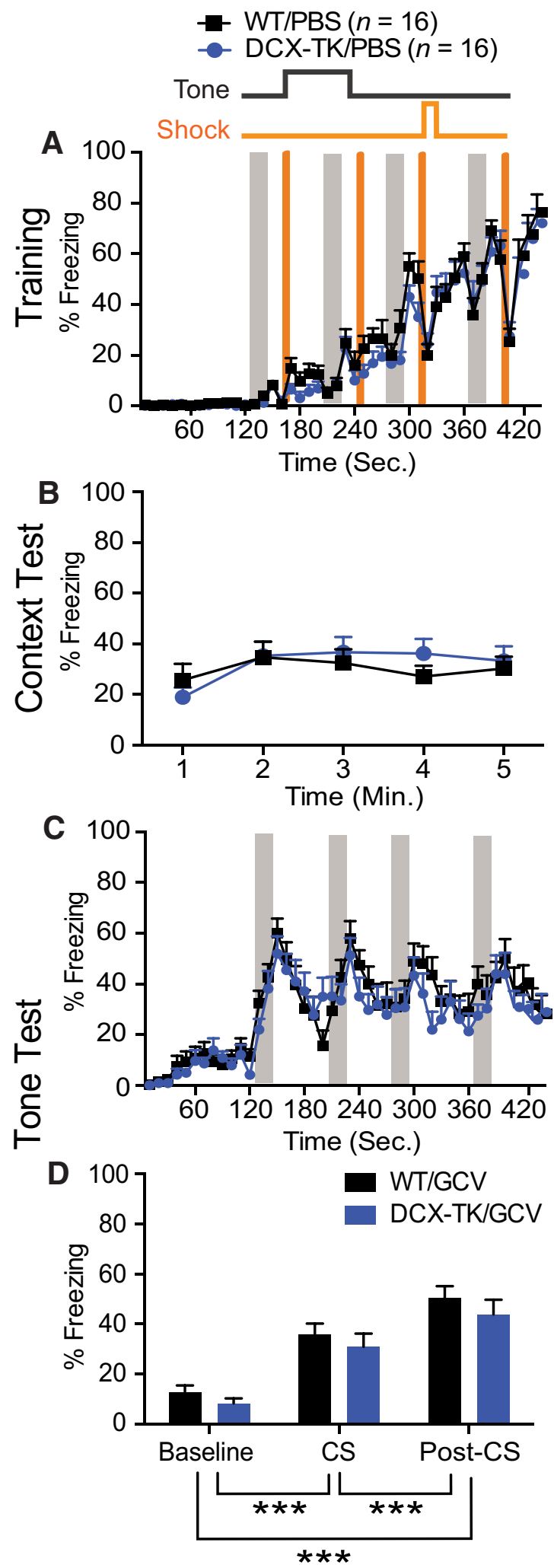

Figure 7. Trace fear conditioning in vehicle-treated DCX-TK and WT mice. DCX-TK or WT mice were given trace conditioning 1 week after the 2 week PBS treatment. $A$, In the training session there was no effect of genotype on freezing. $\boldsymbol{B}$, Freezing during the test of context-elicited fear. There was no effect of genotype on freezing. $C$, Freezing during the test for tone-elicited fear in a novel context. $\boldsymbol{D}$, Mean freezing during the tone test. Both genotypes displayed freezing in response to the tone, and there was no effect of genotype on freezing; ${ }^{* * *} p<0.001$. 

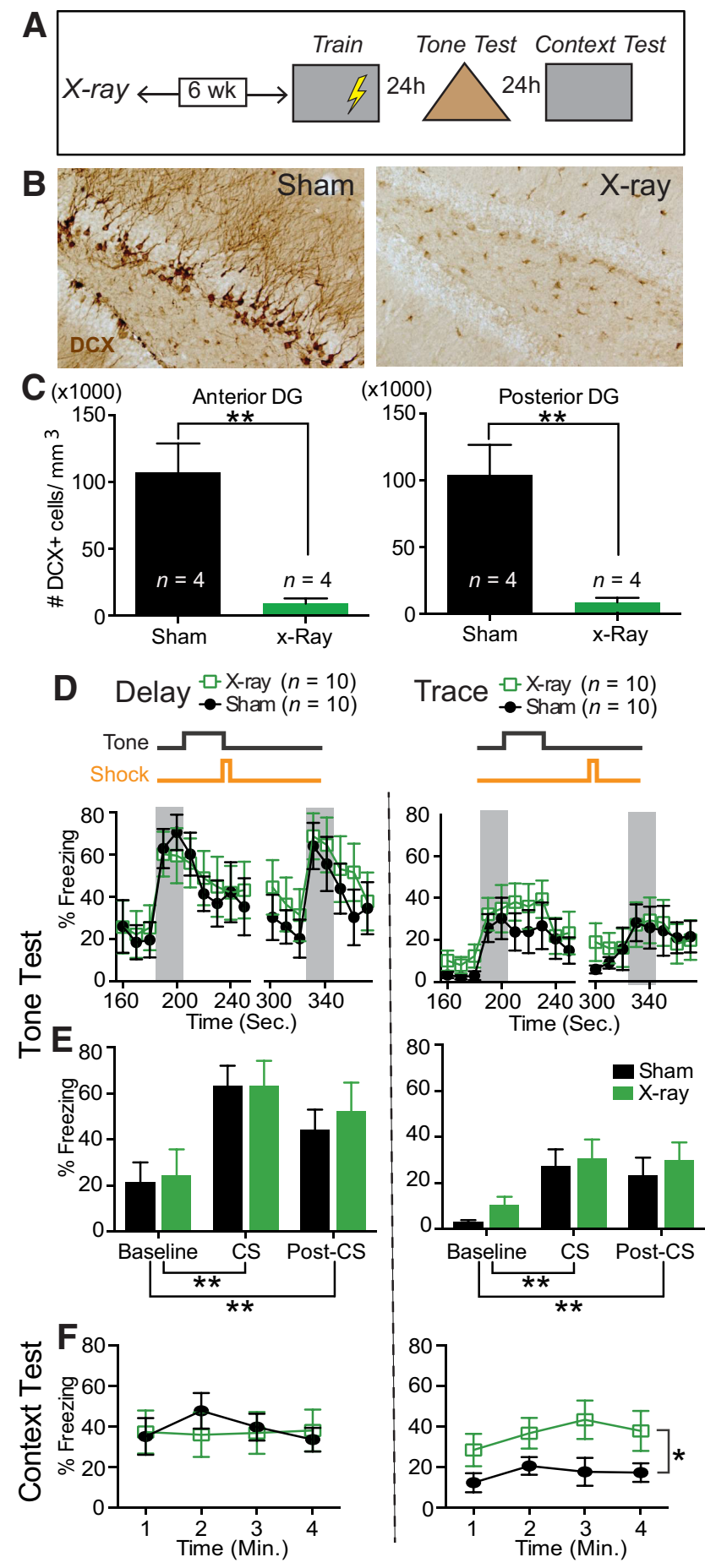

Figure 8. Effect of $x$-irradiation-induced ablation of adult neurogenesis on delay and trace fear conditioning. $A$, Fear conditioning was conducted 6 weeks after the first of three doses of $\mathrm{x}$-irradiation. $\boldsymbol{B}, \boldsymbol{C}, \mathrm{DCX}$ immunohistochemistry confirmed that $D C X+$ immature neurons were greatly reduced in $x$-irradiated mice. $\boldsymbol{D}$, Freezing as a function of time during the tone test session. $\boldsymbol{E}$, Mean freezing during the baseline period ( $20 \mathrm{~s}$ before presentation of the first tone), the tone presentations, and the $20 \mathrm{~s}$ following each tone presentation. In both delay and trace training, there was a significant effect of period but no effect of $x$-irradiation treatment or the interaction. $\boldsymbol{F}$, Consistent with the DCX-TK experiments, in the context test, there was an effect of neurogenesis ablation in trace conditioning but not delay conditioning. In trace conditioning, $x$-irradiated mice displayed more contextelicited freezing than sham controls, but in delay conditioning the groups did not differ; ${ }^{*} p<0.05,{ }^{* *} p<0.01$. were placed into the novel context to measure nonassociative freezing to the tone. Although mice had not received tone-shock pairings, both WT/GCV and DCX-TK/GCV mice exhibited freezing during and after the tone at levels comparable with those produced by trace conditioning (Fig. 9C). As in the previous experiments, we analyzed freezing during three periods (Fig. 9D): baseline (20 s before tone), tone, and post-tone (20 s after tone). There was a significant main effect of Period $\left(F_{(2,114)}=16.47, p<\right.$ $0.001)$. Tukey's test confirmed that freezing during the post-tone period was significantly higher than that during the baseline and the tone periods (baseline vs post-tone, $p<0.001$; tone vs posttone, $p<0.001$ ). As shown in Figures $5 B, C$ and $7 A$, mice exhibited little or no freezing in response to the first tone presentation during delay and trace fear conditioning. This indicates that posttone freezing was caused by prior shock exposure and does not occur in unshocked mice. DCX-TK/GCV mice significantly froze more than WT/GCV mice on the whole (Genotype, $F_{(2,114)}=$ $4.19, p=0.045$; Genotype $\times$ Period, $\left.F_{(2,114)}=0.61, p=0.544\right)$. These data were further analyzed as a function of trial during the tone or post-tone periods. In the tone periods (Fig. 9E), there was significant Genotype effect (Genotype, $F_{(1,57)}=4.18, p=0.045$; Genotype $\times$ Trial, $\left.F_{(3,171)}=1.99, p=0.117\right)$. In the post-tone periods (Fig. $9 F$ ), there was significant interaction of Genotype $X$ Trial $\left(F_{(3,171)}=3.41, p=0.019\right)$. These results indicate that shock-alone fear conditioning induces nonassociative freezing, and freezing is exaggerated in mice lacking adult neurogenesis.

\section{Arrest of neurogenesis potentiates the nonassociative effects of fear conditioning}

These results suggest that fear conditioning may induce a nonassociative change in emotional responsiveness that causes mice to exhibit fear in response to a tone stimulus that was never paired with shock. If fear conditioning, in fact, induces generalized changes in emotionality, these changes should be evident in another assay of emotional function. To test this hypothesis, we assessed open field behavior in WT and DCX-TK treated with GCV as described above. One subgroup of mice was subjected to fear conditioning (using the delay or shock-alone protocols described above) before open field testing. The other subgroup was tested in the open field without prior exposure to fear conditioning.

Consistent with earlier studies (David et al., 2009; Jaholkowski et al., 2009), in mice that were not fear conditioned there was no significant effect of neurogenesis ablation on open field activity (Fig. 10A-D; REML: Center Time: Genotype, $F_{(1,25)}=0.30, p=$ 0.588 , Genotype $\times$ Time, $F_{(5,125)}=0.84, p=0.527$; Center Distance: Genotype, $F_{(1,25)}=2.97, p=0.097$, Genotype $\times$ Time, $F_{(5,125)}=1.14, p=0.341$; Marginal Distance: Genotype, $F_{(1,25)}=$ $0.03, p=0.873$, Genotype $\times$ Time, $\left.F_{(5,125)}=1.33, p=0.256\right)$. However, among mice that were previously fear conditioned, DCX-TK/GCV mice displayed reduced time and distance in the center zone and a small reduction in marginal distance (Fig. $10 E-H$; REML: Center Time: Genotype $\times$ Time, $F_{(5,125)}=4.86$, $p<0.001$; Center Distance: Group, $F_{(1,25)}=6.30, p=0.019$; Marginal Distance: Genotype $\times$ Time, $\left.F_{(5,125)}=3.25, p=0.009\right)$. After fear conditioning, neurogenesis-arrested DCX-TK/GCV mice displayed elevated anxiety-like behavior in the open field compared with WT mice.

Next we asked whether generalized changes in emotionality after fear conditioning could be detected in another classic test of anxiety-like behavior, the elevated plus maze (EPM). A separate group of mice was treated with GCV for 2 weeks. Beginning 1 week after GCV, the mice were tested in the EPM, then given shock-alone fear conditioning (data included in Fig. 9), and then 
tested a second time in the EPM. We predicted that DCX-TK/GCV mice would display higher anxiety behavior compared with WT mice after but not before fear conditioning.

Consistent with the open field results, before fear conditioning (FC) there was no significant effect of neurogenesis ablation on EPM activity in either open or closed arms (Fig. 11A-D; Before FC: Open time, $t_{(17)}=-0.03, p=0.510$; Open distance, $t_{(17)}=0.30, p=0.382$; Closed time, $t_{(17)}=-0.15, p=0.558$; Closed distance, $t_{(17)}=0.01, p=$ 0.504). However, after fear conditioning, DCX-TK/GCV mice displayed reduced time and distance in the open arms (Fig. $11 A, C$; After FC: Open time, $t_{(17)}=$ $1.78, p=0.047$; Open distance, $t_{(17)}=$ $1.87, p=0.040$, one-tailed $t$ test), but not in the closed arms (Fig. $11 B, D$; After FC: Closed time, $t_{(17)}=-1.32, p=0.898$; Closed distance, $t_{(17)}=0.49, p=0.317$, one-tailed $t$ test). These results confirm that after fear conditioning, neurogenesisarrested DCX-TK/GCV mice displayed elevated anxiety-like behavior compared with WT mice.

A reduced-intensity fear-conditioning procedure reveals a trace-conditioning deficit in DCX-TK mice

In our trace-conditioning experiments, neurogenesis-arrested and control mice showed comparable levels of tone-elicited fear. However, two observations were inconsistent with the conclusion that adult neurogenesis is dispensable for associative trace fear conditioning. First, fear conditioning produced significant nonassociative fear, which could mask an impaired trace CS-US association. Second, after trace conditioning mice lacking adult neurogenesis showed increased context fear compared with control mice, which is suggestive of an impaired ability to associate the trace CS with shock. If the increased context fear in neurogenesis-arrested mice indeed reflects an impaired trace CS-US association, then a revised trace fear conditioning procedure that minimizes nonassociative plasticity should reveal a trace conditioning deficit in mice lacking neurogenesis.

Based on evidence that shock intensity, tone intensity, intertrial interval (ITI) length, and animal handling influence the prevalence of nonassociative plasticity in fear conditioning (Kamprath and Wotjak, 2004; Smith et al., 2007; Burman et al., 2014), we developed an alternate trace fear-conditioning procedure (Protocol 2) that minimized nonassociative tone-elicited fear. Relative to the original protocol, shock and tone intensity were reduced, ITI was increased, and mice were given additional handling before training. Using WT mice, we confirmed that the alternate trace fear-conditioning protocol minimized nonassociative tone freezing. Separate groups of WT mice were trained with trace, unpaired, or shock-alone protocols (data not shown). In the tone test session, the REML model revealed significant
WT/GCV $(n=27)$

DCX-TK/GCV $(n=32)$ 1
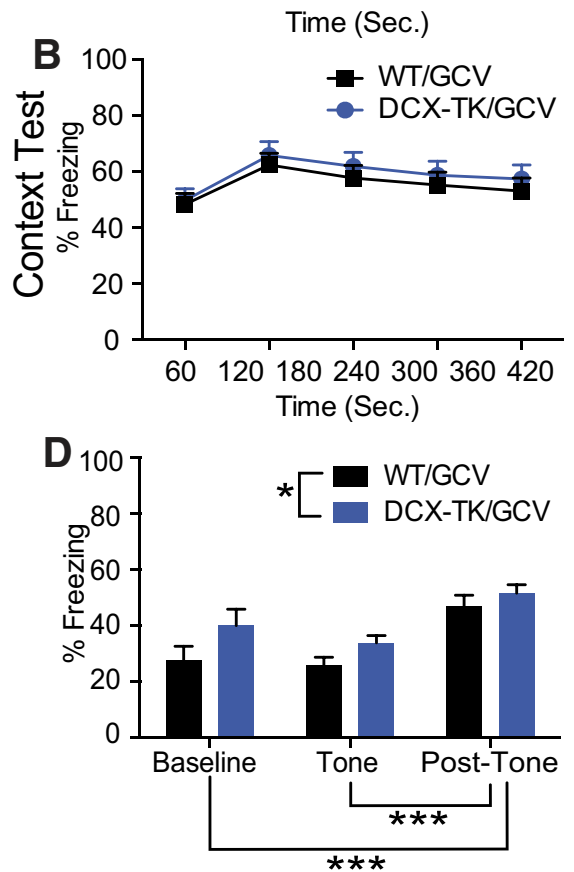

F $80_{7} \quad$ Post-tone

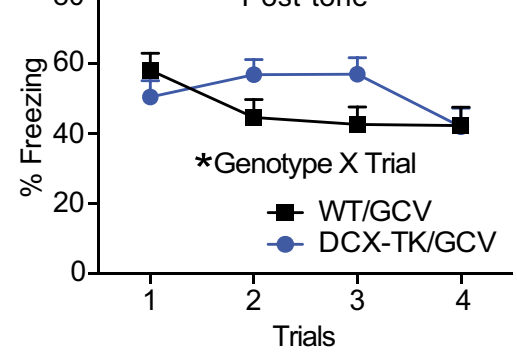

Figure 9. Evidence for nonassociative tone-elicited freezing. DCX-TK/GCV and WT/GCV mice received shock-alone ("foreDean freezing during the post-tone period exceeded that during the baseline and tone periods. DCX-TK/GCV mice significantly froze more than WT/GCV mice during the tone period $(\boldsymbol{E})$. In the trace periods $(\boldsymbol{F})$, there was a Genotype $\times$ Trial interaction, but the genotype effect did not reach significance; ${ }^{*} p<0.05 ;{ }^{* * *} p<0.001$.

main effects of Protocol and Period (Protocol, $F_{(2,15)}=10.32$, $p=0.002$; Period, $\left.F_{(2,30)}=21.14, p<0.001\right)$. There was no effect of conditioning protocol on freezing during the baseline period (one-way ANOVA: $F_{(2,17)}=2.64, p=0.104$ ). However, the trace-trained mice froze significantly more than the unpaired or shock-alone groups during the $\operatorname{CS}\left(F_{(2,17)}=5.37, p=0.017\right.$; Tukey: Trace vs Unpaired or Shock alone, $p<0.05)$ and the Post-CS periods $\left(F_{(2,17)}=10.80, p=0.001\right.$; Tukey: Trace vs Unpaired or Shock alone, $p<0.01)$. These data confirm that this protocol produces tone-elicited fear that is largely associative.

Next, we trained WT and DCX-TK mice in the alternate traceconditioning protocol 3 weeks after the start of a 2 week GCV treatment. On the training day, both DCX-TK/GCV and WT/ GCV groups reached $\sim 80 \%$ freezing after the last trial of training (data not shown). The freezing levels in time bins (10 s) were analyzed using REML. There was no effect of Genotype or the Genotype $\times$ Time interaction (Genotype, $F_{(1,19)}=1.14, p=$ 0.299 ; Genotype $\times$ Time, $\left.F_{(119,2261)}=1.13, p=0.172\right)$. On the 
A

B
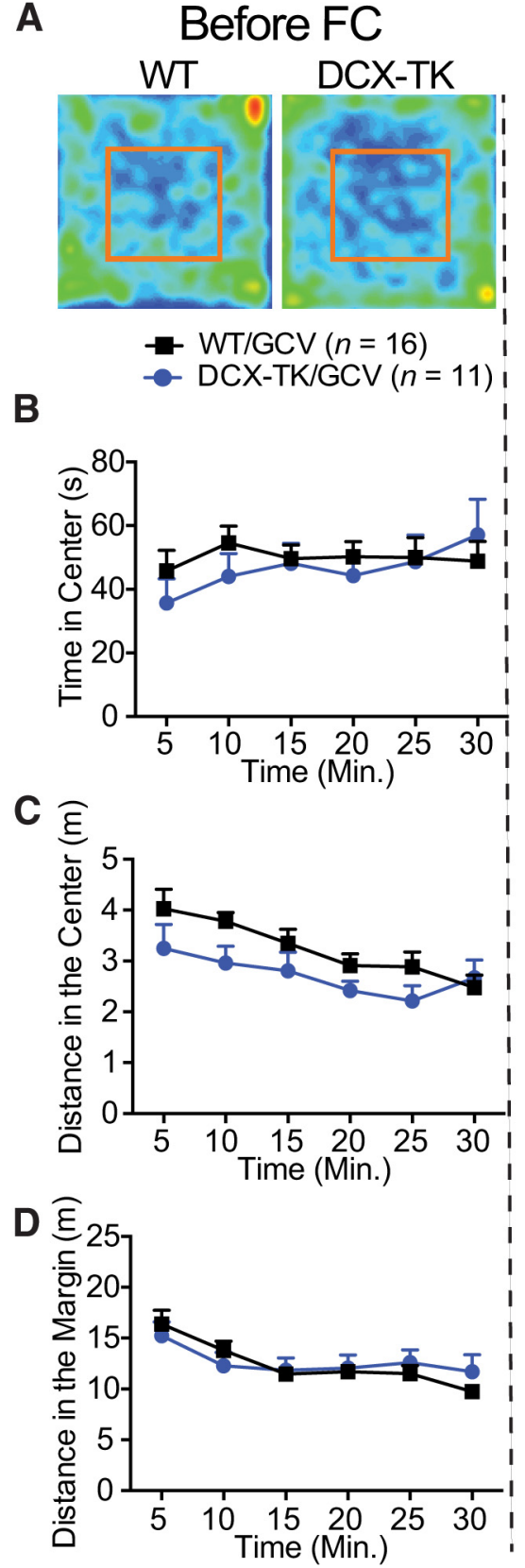

E

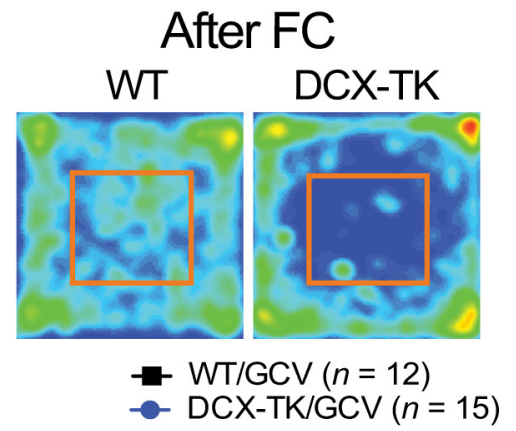

$\mathbf{F}$

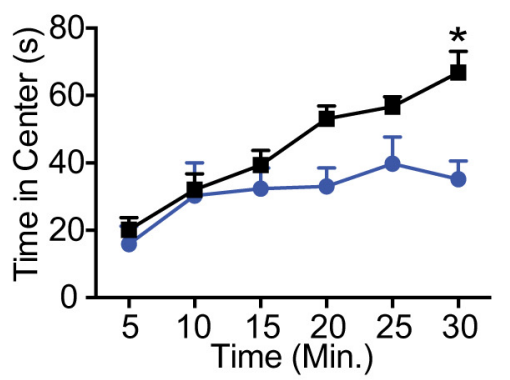

G
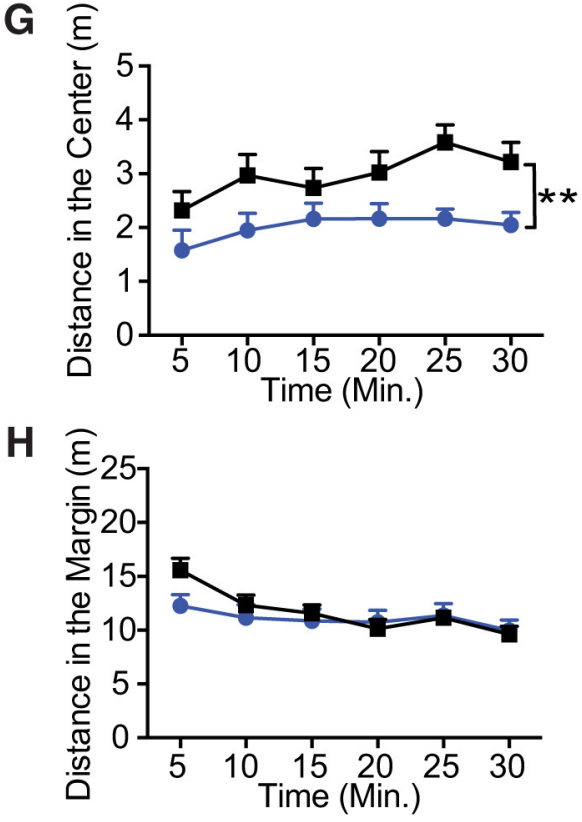

Figure 10. Effect of fear conditioning (FC) on behavior in the open field. Separate groups of DCX-TK/GCV and WT/GCV mice were tested in the open field without prior fear conditioning or $3 \mathrm{~d}$ after fear conditioning. $A, E, O$ ccupancy plots for representative individual mice. $\boldsymbol{A}-\boldsymbol{D}$, Among mice without prior fear conditioning, there was no effect of genotype on open field behavior. $\boldsymbol{E}-\boldsymbol{H}$, In contrast, after fear conditioning, DCX-TK/GCV mice displayed reduced center time $(\boldsymbol{F})$, center distance $(\boldsymbol{G})$, and marginal distance (H) as compared with WT/GCV mice; ${ }^{*} p<0.05,{ }^{* *} p<0.01$.

next day, mice were placed into the original training context for a test of context-elicited fear. The genotypes did not differ significantly (Fig. $12 A$; Genotype, $F_{(1,18)}=0.22, p=0.644$; Genotype $\times$ Time, $\left.F_{(4,72)}=0.55, p=0.670\right)$. On the third day, mice were placed into the novel context to test tone-elicited fear (Fig. 12B). The freezing responses during the CS, post-CS, and ITI periods were analyzed as a function of trial. In both the CS (Fig. 12C) and post-CS periods DCX-TK/GCV mice exhibited significantly lower freezing than WT/GCV mice. (Genotype, $F_{(1,19)}>7$, ps $<$ 0.02 ). The effect of genotype during the ITI periods (Fig. 12E) did not reach significance $\left(F_{(1,19)}=4.21, p=0.054\right)$. In summary, arrest of adult neurogenesis impaired associative trace fear conditioning.

Recent studies have reached different conclusions about the time course of memory deficits arising from the arrest of neurogenesis. Denny et al. (2012) reported that effects in context fear conditioning and novel object recognition arise 4-6 week after x-irradiation. In contrast, Deng et al. (2009) reported that water maze impairments arise within 3-4 weeks after TK-mediated ablation and that normal performance is restored 5-6 weeks after the ablation. To determine whether trace-conditioning impairments in DCXTK mice are transient or permanent, we trained WT/GCV and DCX-TK/GCV mice in the alternate trace conditioning protocol 6 weeks after the start of a 2 week GCV infusion (Fig. 12F-J). On the training day (data not shown), freezing levels increased more rapidly in DCX-TK/GCV mice than in WT/GCV mice (Genotype $\times$ Time, $\left.F_{(119,1904)}=1.33, p=0.011\right)$. However, freezing levels after the final shock were equivalent between the two genotypes $\left(t_{(16)}=-1.33, p=0.20\right)$. On the next day, mice were placed into the original training context for a test of context-elicited fear. The genotypes did not differ significantly (Fig. 12F; Genotype, $F_{(1,16)}=1.36, p=0.260$; Genotype $\times$ Time, $\left.F_{(4,64)}=0.43, p=0.783\right)$. On the third day, mice were placed into the novel context to test tone-elicited fear (Fig. 12G). The freezing responses during the CS, post-CS, and ITI periods were analyzed as a function of trial. In the CS periods (Fig. 12H), the Genotype $\times$ Trial interaction reached significance $\left(F_{(4,64)}=2.94, p=0.027\right)$. Post hoc tests confirmed that DCX-TK/GCV mice exhibited lower freezing than WT mice during the final tone presentation. There was no significant effect of Genotype in the post-CS periods (Fig. 12I; Genotype, $F_{(1,16)}=2.322, p=0.147$; Genotype $\times$ Trial, $F_{(4,64)}=1.347, p=$ 0.263 ). In the ITI periods (Fig. 12J), there was a strong Genotype effect $\left(F_{(1,16)}=10.402, p=0.005\right)$.

To confirm that neurogenesis was suppressed in DCX-TK mice 4 weeks after termination of GCV, we quantified DCX+ cells in the SGZ. The number of $\mathrm{DCX}+$ cells was greatly reduced in both the anterior DG (Fig. $12 \mathrm{~K}, L ; t_{(6)}=6.41, p<0.001$ ) and the posterior DG (Fig. 12M; $\left.t_{(6)}=4.39, p=0.004\right)$ of DCX-TK mice as compared with WT mice.

In summary, neurogenesis-arrested DCX-TK mice displayed impaired performance in a trace-conditioning procedure that minimized nonassociative learning. The impairment in DCX-TK transgenic mice was somewhat smaller 6 weeks after neurogenesis ablation than 3 weeks after the ablation. 
Because neurogenesis was still suppressed at 6 weeks after ablation, the apparent recovery of behavioral performance suggests the presence of compensatory processes capable of restoring cognitive function in the absence of adult neurogenesis (Singer et al., 2011).

\section{Discussion}

We characterized trace and delay fear conditioning and anxiety-like behavior using a novel chemogenetic approach for selectively ablating neural progenitor cells in adult mice. There were three main results. First, selective ablation of proliferating DCX + cells caused a robust and specific arrest of adult neurogenesis, consistent with evidence that DCX + progenitors are a lineage-restricted population (Brown et al., 2003). Second, the effects of arresting neurogenesis on trace fear conditioning were dependent on the conditioning protocol. When the protocol produced significant nonassociative fear, arrest of adult neurogenesis potentiated fear behavior; with a procedure that minimized nonassociative plasticity, arrest of neurogenesis impaired associative fear. Finally, the effects of neurogenesis ablation on anxiety-like behavior were modulated by the fear-conditioning protocol. Consistent with previous studies (David et al., 2009; Jaholkowski et al., 2009), arrest of neurogenesis had no effect on anxiety-like behavior in mice not subjected to fear conditioning. However, after fear conditioning, neurogenesis-arrested mice displayed increased anxiety-like behavior in the open field and elevated plus maze. The results suggest that adult neurogenesis modulates emotional learning via two distinct but opposing mechanisms: it supports associative trace conditioning while also buffering against the generalized, nonassociative fear and anxiety caused by fear conditioning.

Although fear conditioning is usually studied as a model of associative learning, it can induce changes in behavior that are not readily explained via associative mechanisms. For instance, mice previously exposed to footshock display increased anxietylike behavior in the open field and display fear responses to a tone never paired with shock. There is debate about whether these behaviors are truly nonassociative (Davis, 1989; Hitchcock, 1989; Richardson, 2000), but recent evidence indicates that such behaviors can be induced even when the conditioning procedure fails to produce associative fear (Sauerhöfer et al., 2012). In the current study, exposure to footshocks caused generalized changes in behavior similar to those reported previously (Kamprath and Wotjak, 2004). Fear-conditioned mice displayed reduced center exploration in the open field as compared with mice that were not fear conditioned. In addition, mice exposed to footshock displayed freezing responses to a tone that was never paired with shock. Arrest of neurogenesis appeared to potentiate the nonassociative effects of fear conditioning. In the absence of fear conditioning, arrest of neurogenesis had no effect on open field behavior. However, among mice that were fear conditioned, neurogenesis-arrested mice displayed reduced exploration in the
Open Time
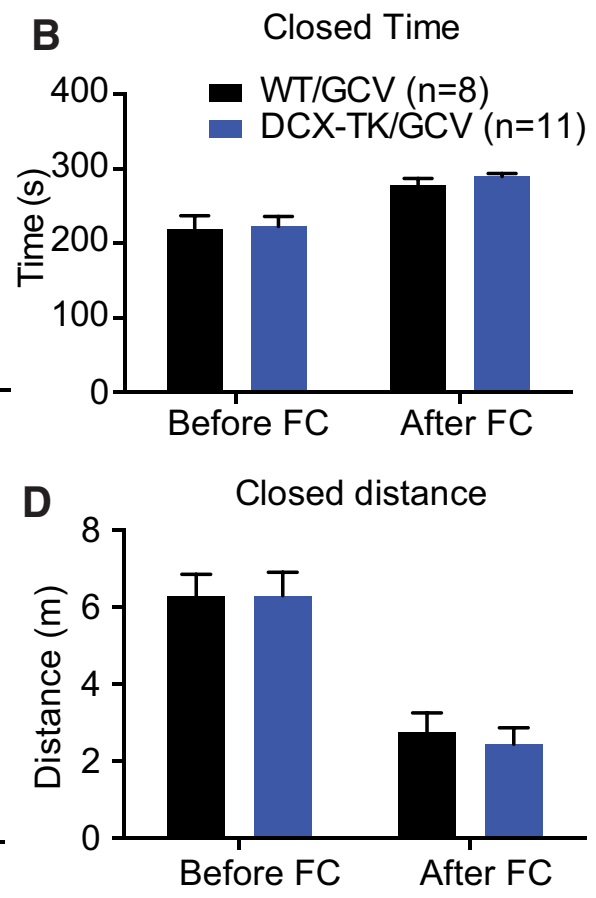

Figure 11. Effect of fear conditioning on behavior in the elevated plus maze. DCX-TK/GCV and WT/GCV mice were tested in the elevated plus maze before fear conditioning $(\mathrm{FC})$ and after fear conditioning. $\boldsymbol{A}-\boldsymbol{D}$, Before fear conditioning, there was no effect of genotype on activity in the open or closed arms. $\boldsymbol{A}, \boldsymbol{C}$, However, after fear conditioning, mice lacking neurogenesis exhibited less time $(\boldsymbol{A})$ and traveled distance on the open $\operatorname{arms}(\boldsymbol{C}) ;{ }^{*} p<0.05$.

open field. The results suggest that arrest of neurogenesis sensitized mice to the anxiogenic effects of fear conditioning.

This observation is consistent with recent data suggesting that adult-born neurons buffer the behavioral and endocrine response to acute stressors. Acute restraint or novel environment stress causes a larger corticosterone surge and more severe induction of anxietylike behavior in neurogenesis-arrested than control mice (Schloesser et al., 2010; Snyder et al., 2011). The circuit mechanisms for these effects are not well understood, but it is thought that suppression of adult neurogenesis impairs hippocampal feedback regulation of HPA axis. Corticosterone and its upstream modulator corticotropin-releasing factor (CRF) appear to be necessary for acute stress to induce long-term increases in anxiety-like behavior (Adamec et al., 2010; Clay et al., 2011; Jakovcevski et al., 2011). Thus, fear conditioning may be more anxiogenic to neurogenesis-arrested mice because these mice experience a more pronounced induction of corticosterone and/or CRF by fear conditioning.

An unanswered question is whether the increased anxiety-like behavior in neurogenesis-arrested mice after fear conditioning itself represents a cognitive impairment. One possibility is that the increased anxiety-like behavior by neurogenesis-arrested mice in the open field reflects overgeneralization of associative context fear, similar to that reported in context fear discrimination experiments ( $\mathrm{Tr}$ onel et al., 2010; Sahay et al., 2011; Niibori et al., 2012). These data are not fully consistent with this hypothesis. Neurogenesis-arrested and control mice displayed similar levels of context-elicited fear in both the training and alternate contexts in delay conditioning, indicating that arrest of neurogenesis does not cause a general increase in context fear generalization. Similarly, in the reduced-intensity traceconditioning protocol, alternate-context fear was comparable in WT and neurogenesis-arrested mice. The only procedure yielding an unambiguous increase in fear generalization in neurogenesis-arrested mice was shock-alone conditioning (Fig. 9). The pattern of data 

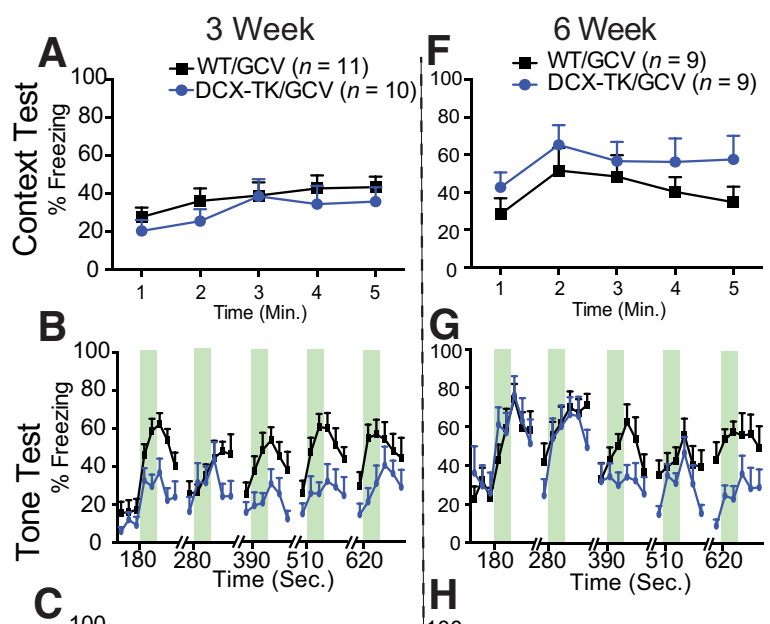

G
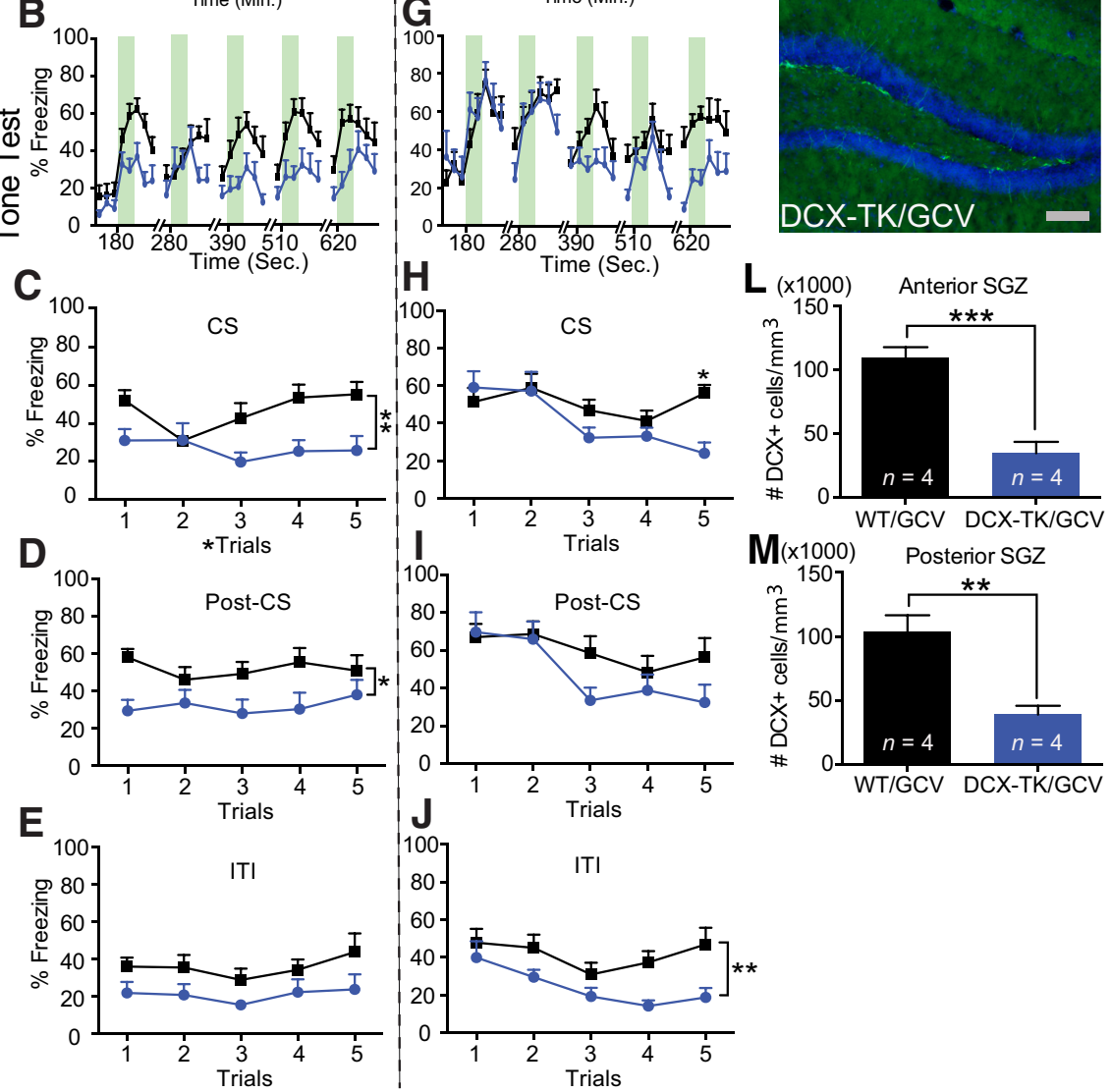

Figure 12. Effect of DCX-TK-mediated ablation in an alternate trace fear-conditioning procedure that minimized nonassociative tone freezing. DCX-TK and WT mice were treated with GCV for 2 weeks and subjected to trace fear conditioning either 3 weeks $(\boldsymbol{A}-\boldsymbol{E})$ or 6 weeks $(\boldsymbol{F}-\boldsymbol{M})$ after the start of GCV. $\boldsymbol{A}, \boldsymbol{F}$, Freezing during the test of context-elicited fear. There was no effect of genotype in 3 week $(\boldsymbol{A})$ or 6 week $(\boldsymbol{F})$ experiments. $\boldsymbol{B}-\boldsymbol{E}, \boldsymbol{G}-\boldsymbol{J}$, Freezing during the test for tone-elicited fear in a novel context. The freezing responses were analyzed as a function of trial during the $C S$, post-CS, and ITI periods. In the 3 week conditioning, DCX-TK mice displayed reduced fear during the $C S$ and post-CS periods $(\boldsymbol{C}, \boldsymbol{D})$. In the 6 week condition, DCX-TK mice displayed reduced fear during the final CS presentation $(\boldsymbol{H})$ and during the ITI periods $(\boldsymbol{J})$. $\boldsymbol{K}-\boldsymbol{M}$, Depletion of DCX+ immature neurons in DCX-TK mice 6 weeks after the start of GCV. $\boldsymbol{K}$, Representative images of DCX immunohistochemistry in the DG. The number of DCX+cells in anterior $(\boldsymbol{L})$ and posterior DG $(\boldsymbol{M})$ was greatly reduced in DCX-TK/GCV mice relative to WT/GCV mice. Scale bars: $100 \mu \mathrm{m} .{ }^{*} p<$ $0.05,{ }^{* *} p<0.01,{ }^{* * *} p<0.001$.

indicates that the effects of neurogenesis arrest on fear generalization are highly procedure dependent. Specifically, effects on fear generalization appear to be most profound in procedures involving strong aversive stimulation that cannot readily be predicted using discrete CSs.

With an intensive trace fear-conditioning procedure neurogenesis-arrested mice displayed elevated context fear compared with WT controls. We propose a cue competition mechanism to explain this phenotype. Context and discrete cues can compete for associative strength (Urushihara and Miller, 2009; Urcelay and Miller, 2014). As a consequence, manipulations that degrade the contingency between a discrete CS and US sometimes increase the strength of context conditioning (Detert et al., 2008; Urcelay and Miller, 2010). We hypothesize that the increased context condition- ing in neurogenesis-arrested mice reflects impaired associative conditioning to the trace CS. In the intensive conditioning protocol, this impairment was not observable because of the high level of nonassociative tone-elicited freezing. However, when a protocol of more moderate intensity was used, nonassociative tone fear was reduced, and neurogenesis-arrested mice displayed impaired conditioned fear to the trace CS.

While there is abundant evidence that participating in trace conditioning enhances survival of adult-born neurons, studies examining the requirement of adult neurogenesis in trace conditioning have reached contradictory conclusions. Arrest of neurogenesis via systemic administration of an antimitotic compound or $\mathrm{x}$-irradiation in rats impaired trace fear and trace eyelid conditioning (Shors et al., 2001, 2002; Achanta et al., 2009). However, two studies examining the role of neurogenesis in mouse trace conditioning failed to detect impairments (Cuppini et al., 2006; Jaholkowski et al., 2009). Mice and rats show different cellular and behavioral responses to stress (Armario and Castellanos, 1984; Griebel et al., 1997; Bain et al., 2004), which raises the possibility that the effects of neurogenesis ablation are more readily masked by nonassociative fear in mice than in rats.

Two mechanisms have been proposed to explain the hippocampus-dependence of trace conditioning. One idea is that the hippocampus maintains the CS representation during the trace interval. Supporting this idea, neurons in entorhinal cortex and hippocampus display sustained activity during the retention interval in working memory tasks (Young et al., 1997; Axmacher et al., 2007). An alternate but not mutually exclusive idea is that hippocampus plays a discriminative role. Successful trace conditioning requires that subjects distinguish between the trace interval and the ITI (Bolles et al., 1978). Distinguishing between these two stimulus-free periods appears to require the hippocampus, because deficits in trace conditioning caused by hippocampus lesions can be rescued by providing a cue to help subjects differentiate between the trace and ITI (Bangasser et al., 2006). Recent evidence that adult neurogenesis supports behavioral pattern separation-the ability to discriminate between complex stimuli with shared or similar features (Clelland et al., 2009; Tronel et al., 2010; Sahay et al., 2011; Swan et al., 2014)—suggests the possibility that adult neurogenesis contributes to trace conditioning by supporting the discrimination between the trace and ITI.

Ablation of adult neurogenesis by DCX-TK/GCV or $\mathrm{x}$-irradiation caused increased context fear in trace conditioning. The consistency of the phenotype across two ablation methods suggests that the phenotype was caused by ablation of neurogenesis 
rather than a side effect of either procedure. Furthermore, because the targeted $\mathrm{x}$-irradiation procedure arrests neurogenesis in hippocampus but not SVZ (Santarelli et al., 2003), the increased context fear can be attributed to the loss of hippocampal neurogenesis. Nevertheless, the phenotypes of DCX-TK/GCV and x-irradiated mice were not identical. DCX-TK mice displayed elevated pretone fear in the novel context as compared with controls, whereas in $\mathrm{x}$-irradiated mice pretone fear was not significantly elevated. The difference may relate to differences in the conditioning protocol. In the irradiation experiment, mice were pre-exposed to the conditioning and alternate contexts before training, whereas in the DCX-TK experiments mice were not pre-exposed. Context pre-exposure can affect the strength of context conditioning and modulate context generalization (Urcelay and Miller, 2010; Iordanova and Honey, 2012). Perhaps more important, the training and novel contexts were more different in the x-irradiation experiment than DCX-TK experiments. In the DCX-TK experiments, both contexts had hard floors, whereas in $\mathrm{x}$-irradiation experiments the novel context floor was covered with bedding. Across a variety of learning paradigms, the effects of neurogenesis manipulations on generalization/discrimination tend to become more pronounced as the discriminability of the stimuli decreases (Creer et al., 2010; Sahay et al., 2011; Nakashiba et al., 2012; Niibori et al., 2012; Bekinschtein et al., 2014). Thus, the DCX-TK conditioning protocol may be been more sensitive to effects of neurogenesis ablation on context generalization, because of the use of more similar contexts.

The role of adult neurogenesis in behavior continues to be a subject of debate, due, in part, to a literature that includes inconsistent and sometimes contradictory findings (Castilla-Ortega et al., 2011). The conflicts among studies raise the possibility that the contribution of adult neurogenesis to behavior is modulated by experiential factors. One implication of the current experiments is that the effects of neurogenesis ablation depend on the stress history of the animal. In particular, exposure to strong aversive stimuli can induce an anxiety-like phenotype in neurogenesis-arrested mice that can mask associative deficits in fear conditioning. More generally, the results suggest that adult neurogenesis modulates emotional learning via dual mechanisms: it supports the ability to learn predictive contingencies involving aversive events while buffering against the generalized anxiogenic effects of those events.

\section{References}

Achanta P, Fuss M, Martinez JL Jr (2009) Ionizing radiation impairs the formation of trace fear memories and reduces hippocampal neurogenesis. Behav Neurosci 123:1036-1045. CrossRef Medline

Adamec R, Fougere D, Risbrough V (2010) CRF receptor blockade prevents initiation and consolidation of stress effects on affect in the predator stress model of PTSD. Int J Neuropsychopharmacol 13:747-757. CrossRef Medline

Airan RD, Meltzer LA, Roy M, Gong Y, Chen H, Deisseroth K (2007) Highspeed imaging reveals neurophysiological links to behavior in an animal model of depression. Science 317:819-823. CrossRef Medline

Armario A, Castellanos JM (1984) A comparison of corticoadrenal and gonadal responses to acute immobilization stress in rats and mice. Physiol Behav 32:517-519. CrossRef Medline

Axmacher N, Mormann F, Fernández G, Cohen MX, Elger CE, Fell J (2007) Sustained neural activity patterns during working memory in the human medial temporal lobe. J Neurosci 27:7807-7816. CrossRef Medline

Bain MJ, Dwyer SM, Rusak B (2004) Restraint stress affects hippocampal cell proliferation differently in rats and mice. Neurosci Lett 368:7-10. CrossRef Medline

Bangasser DA, Waxler DE, Santollo J, Shors TJ (2006) Trace conditioning and the hippocampus: the importance of contiguity. J Neurosci 26:87028706. CrossRef Medline

Bekinschtein P, Kent BA, Oomen CA, Clemenson GD, Gage FH, Saksida LM, Bussey TJ (2014) Brain-derived neurotrophic factor interacts with adult-born immature cells in the dentate gyrus during consolidation of overlapping memories. Hippocampus 24:905-911. CrossRef Medline

Beltinger C, Fulda S, Kammertoens T, Meyer E, Uckert W, Debatin KM (1999) Herpes simplex virus thymidine kinase/ganciclovir-induced apoptosis involves ligand-independent death receptor aggregation and activation of caspases. Proc Natl Acad Sci U S A 96:8699-8704. CrossRef Medline

Bolles RC, Collier AC, Bouton ME, Marlin NA (1978) Some tricks for ameliorating the trace-conditioning deficit. Bull Psychonom Soc 11:403-406. CrossRef

Brahmachari S, Fung YK, Pahan K (2006) Induction of glial fibrillary acidic protein expression in astrocytes by nitric oxide. J Neurosci 26:4930-4939. CrossRef Medline

Brown JP, Couillard-Després S, Cooper-Kuhn CM, Winkler J, Aigner L, Kuhn HG (2003) Transient expression of doublecortin during adult neurogenesis. J Comp Neurol 467:1-10. CrossRef Medline

Burman MA, Simmons CA, Hughes M, Lei L (2014) Developing and validating trace fear conditioning protocols in C57BL/6 mice. J Neurosci Methods 222:111-117. CrossRef Medline

Bush TG, Savidge TC, Freeman TC, Cox HJ, Campbell EA, Mucke L, Johnson MH, Sofroniew MV (1998) Fulminant jejuno-ileitis following ablation of enteric glia in adult transgenic mice. Cell 93:189-201. CrossRef Medline

Castilla-Ortega E, Pedraza C, Estivill-Torrús G, Santín LJ (2011) When is adult hippocampal neurogenesis necessary for learning? Evidence from animal research. Rev Neurosci 22:267-283. CrossRef Medline

Clark PJ, Brzezinska WJ, Thomas MW, Ryzhenko NA, Toshkov SA, Rhodes JS (2008) Intact neurogenesis is required for benefits of exercise on spatial memory but not motor performance or contextual fear conditioning in C57BL/6J mice. Neuroscience 155:1048-1058. CrossRef Medline

Clay R, Hebert M, Gill G, Stapleton LA, Pridham A, Coady M, Bishop J, Adamec RE, Blundell JJ (2011) Glucocorticoids are required for extinction of predator stress-induced hyperarousal. Neurobiol Learn Mem 96: 367-377. CrossRef Medline

Clelland CD, Choi M, Romberg C, Clemenson GD Jr, Fragniere A, Tyers P, Jessberger S, Saksida LM, Barker RA, Gage FH, Bussey TJ (2009) A functional role for adult hippocampal neurogenesis in spatial pattern separation. Science 325:210-213. CrossRef Medline

Creer DJ, Romberg C, Saksida LM, van Praag H, Bussey TJ (2010) Running enhances spatial pattern separation in mice. Proc Natl Acad Sci U S A 107:2367-2372. CrossRef Medline

Cuppini R, Bucherelli C, Ambrogini P, Ciuffoli S, Orsini L, Ferri P, Baldi E (2006) Age-related naturally occurring depression of hippocampal neurogenesis does not affect trace fear conditioning. Hippocampus 16:141148. CrossRef Medline

Cushman JD, Maldonado J, Kwon EE, Garcia AD, Fan G, Imura T, Sofroniew MV, Fanselow MS (2012) Juvenile neurogenesis makes essential contributions to adult brain structure and plays a sex-dependent role in fear memories. Front Behav Neurosci 6:3. CrossRef Medline

David DJ, Samuels BA, Rainer Q, Wang JW, Marsteller D, Mendez I, Drew M, Craig DA, Guiard BP, Guilloux JP, Artymyshyn RP, Gardier AM, Gerald C, Antonijevic IA, Leonardo ED, Hen R (2009) Neurogenesisdependent and -independent effects of fluoxetine in an animal model of anxiety/depression. Neuron 62:479-493. CrossRef Medline

Davis M (1989) Sensitization of the acoustic startle reflex by footshock. Behav Neurosci 103:495-503. CrossRef Medline

Deng W, Saxe MD, Gallina IS, Gage FH (2009) Adult-born hippocampal dentate granule cells undergoing maturation modulate learning and memory in the brain. J Neurosci 29:13532-13542. CrossRef Medline

Denny CA, Burghardt NS, Schachter DM, Hen R, Drew MR (2012) Four- to 6-week-old adult-born hippocampal neurons influence novelty-evoked exploration and contextual fear conditioning. Hippocampus 22:11881201. CrossRef Medline

Detert JA, Kampa ND, Moyer JR Jr (2008) Differential effects of training intertrial interval on acquisition of trace and long-delay fear conditioning in rats. Behav Neurosci 122:1318-1327. CrossRef Medline

Drew MR, Denny CA, Hen R (2010) Arrest of adult hippocampal neurogenesis in mice impairs single- but not multiple-trial contextual fear conditioning. Behav Neurosci 124:446-454. CrossRef Medline

Gould E, Beylin A, Tanapat P, Reeves A, Shors TJ (1999) Learning enhances adult neurogenesis in the hippocampal formation. Nat Neurosci 2:260265. CrossRef Medline 
Griebel G, Perrault G, Sanger DJ (1997) A comparative study of the effects of selective and non-selective 5-HT2 receptor subtype antagonists in rat and mouse models of anxiety. Neuropharmacology 36:793-802. CrossRef Medline

Guo W, Allan AM, Zong R, Zhang L, Johnson EB, Schaller EG, Murthy AC, Goggin SL, Eisch AJ, Oostra BA, Nelson DL, Jin P, Zhao X (2011) Ablation of Fmrp in adult neural stem cells disrupts hippocampus-dependent learning. Nat Med 17:559-565. CrossRef Medline

Hayashi F, Takashima N, Murayama A, Inokuchi K (2008) Decreased postnatal neurogenesis in the hippocampus combined with stress experience during adolescence is accompanied by an enhanced incidence of behavioral pathologies in adult mice. Mol Brain 1:22. CrossRef Medline

Hitchcock JM, Sananes CB, Davis M (1989) Sensitization of the startle reflex by footshock: blockade by lesions of the central nucleus of the amygdala or its efferent pathway to the brainstem. Behav Neurosci 103:509-518. CrossRef Medline

Imayoshi I, Sakamoto M, Kageyama R (2011) Genetic methods to identify and manipulate newly born neurons in the adult brain. Front Neurosci 5:64. CrossRef Medline

Iordanova MD, Honey RC (2012) Generalization of contextual fear as a function of familiarity: the role of within- and between-context associations. J Exp Psychol Anim Behav Process 38:315-321. CrossRef Medline

Ito D, Tanaka K, Suzuki S, Dembo T, Fukuuchi Y (2001) Enhanced expression of Iba1, ionized calcium-binding adapter molecule 1, after transient focal cerebral ischemia in rat brain. Stroke 32:1208-1215. CrossRef Medline

Jaholkowski P, Kiryk A, Jedynak P, Ben Abdallah NM, Knapska E, Kowalczyk A, Piechal A, Blecharz-Klin K, Figiel I, Lioudyno V, Widy-Tyszkiewicz E, Wilczynski GM, Lipp HP, Kaczmarek L, Filipkowski RK (2009) New hippocampal neurons are not obligatory for memory formation; cyclin D2 knock-out mice with no adult brain neurogenesis show learning. Learn Mem 16:439-451. CrossRef Medline

Jakovcevski M, Schachner M, Morellini F (2011) Susceptibility to the longterm anxiogenic effects of an acute stressor is mediated by the activation of the glucocorticoid receptors. Neuropharmacology 61:1297-1305. CrossRef Medline

Kamprath K, Wotjak CT (2004) Nonassociative learning processes determine expression and extinction of conditioned fear in mice. Learn Mem 11:770-786. CrossRef Medline

Kempermann G, Jessberger S, Steiner B, Kronenberg G (2004) Milestones of neuronal development in the adult hippocampus. Trends Neurosci 27:447-452. CrossRef Medline

Klempin F, Kronenberg G, Cheung G, Kettenmann H, Kempermann G (2011) Properties of doublecortin-(DCX)-expressing cells in the piriform cortex compared to the neurogenic dentate gyrus of adult mice. PLoS One 6:e25760. CrossRef Medline

Leuner B, Mendolia-Loffredo S, Kozorovitskiy Y, Samburg D, Gould E, Shors TJ (2004) Learning enhances the survival of new neurons beyond the time when the hippocampus is required for memory. J Neurosci 24:74777481. CrossRef Medline

Leuner B, Gould E, Shors TJ (2006a) Is there a link between adult neurogenesis and learning? Hippocampus 16:216-224. CrossRef Medline

Leuner B, Waddell J, Gould E, Shors TJ (2006b) Temporal discontiguity is neither necessary nor sufficient for learning-induced effects on adult neurogenesis. J Neurosci 26:13437-13442. CrossRef Medline

Leuner B, Glasper ER, Gould E (2009) Thymidine analog methods for studies of adult neurogenesis are not equally sensitive. J Comp Neurol 517: 123-133. CrossRef Medline

Marlin NA (1981) Contextual associations in trace conditioning. Anim Learn Behav 9:519-523. CrossRef

Monje ML, Mizumatsu S, Fike JR, Palmer TD (2002) Irradiation induces neural precursor-cell dysfunction. Nat Med 8:955-962. CrossRef Medline

Nakashiba T, Cushman JD, Pelkey KA, Renaudineau S, Buhl DL, McHugh TJ, Rodriguez Barrera V, Chittajallu R, Iwamoto KS, McBain CJ, Fanselow MS, Tonegawa S (2012) Young dentate granule cells mediate pattern separation, whereas old granule cells facilitate pattern completion. Cell 149:188-201. CrossRef Medline

Nakayama M, Ohara O (2005) Improvement of recombination efficiency by mutation of red proteins. Biotechniques 38:917-924. CrossRef Medline

Niibori Y, Yu TS, Epp JR, Akers KG, Josselyn SA, Frankland PW (2012) Suppression of adult neurogenesis impairs population coding of similar contexts in hippocampal CA3 region. Nat Commun 3:1253. CrossRef Medline

Paxinos GF, Franklin KBJ (2001) The mouse brain in stereotaxic coordinates. New York: Academic.

Quinn JJ, Wied HM, Liu D, Fanselow MS (2009) Post-training excitotoxic lesions of the dorsal hippocampus attenuate generalization in auditory delay fear conditioning. Eur J Neurosci 29:1692-1700. CrossRef Medline

Richardson R (2000) Shock sensitization of startle: learned or unlearned fear? Behav Brain Res 110:109-117. CrossRef Medline

Rudy JW, Huff NC, Matus-Amat P (2004) Understanding contextual fear conditioning: insights from a two-process model. Neurosci Biobehav Rev 28:675-685. CrossRef Medline

Sahay A, Scobie KN, Hill AS, O'Carroll CM, Kheirbek MA, Burghardt NS, Fenton AA, Dranovsky A, Hen R (2011) Increasing adult hippocampal neurogenesis is sufficient to improve pattern separation. Nature 472:466470. CrossRef Medline

Santarelli L, Saxe M, Gross C, Surget A, Battaglia F, Dulawa S, Weisstaub N, Lee J, Duman R, Arancio O, Belzung C, Hen R (2003) Requirement of hippocampal neurogenesis for the behavioral effects of antidepressants. Science 301:805-809. CrossRef Medline

Sauerhöfer E, Pamplona FA, Bedenk B, Moll GH, Dawirs RR, von Hörsten S, Wotjak CT, Golub Y (2012) Generalization of contextual fear depends on associative rather than non-associative memory components. Behav Brain Res 233:483-493. CrossRef Medline

Schloesser RJ, Lehmann M, Martinowich K, Manji HK, Herkenham M (2010) Environmental enrichment requires adult neurogenesis to facilitate the recovery from psychosocial stress. Mol Psychiatry 15:1152-1163. CrossRef Medline

Shors TJ, Miesegaes G, Beylin A, Zhao M, Rydel T, Gould E (2001) Neurogenesis in the adult is involved in the formation of trace memories. Nature 410:372-376. CrossRef Medline

Shors TJ, Townsend DA, Zhao M, Kozorovitskiy Y, Gould E (2002) Neurogenesis may relate to some but not all types of hippocampal-dependent learning. Hippocampus 12:578-584. CrossRef Medline

Singer BH, Gamelli AE, Fuller CL, Temme SJ, Parent JM, Murphy GG (2011) Compensatory network changes in the dentate gyrus restore long-term potentiation following ablation of neurogenesis in young-adult mice. Proc Natl Acad Sci U S A 108:5437-5442. CrossRef Medline

Smith DR, Gallagher M, Stanton ME (2007) Genetic background differences and nonassociative effects in mouse trace fear conditioning. Learn Mem 14:597-605. CrossRef Medline

Snyder JS, Soumier A, Brewer M, Pickel J, Cameron HA (2011) Adult hippocampal neurogenesis buffers stress responses and depressive behaviour. Nature 476:458 -461. CrossRef Medline

Solomon PR, Vander Schaaf ER, Thompson RF, Weisz DJ (1986) Hippocampus and trace conditioning of the rabbit's classically conditioned nictitating membrane response. Behav Neurosci 100:729-744. CrossRef Medline

Swan AA, Clutton JE, Chary PK, Cook SG, Liu GG, Drew MR (2014) Characterization of the role of adult neurogenesis in touch-screen discrimination learning. Hippocampus 24:1581-1591. CrossRef Medline

Tronel S, Fabre A, Charrier V, Oliet SH, Gage FH, Abrous DN (2010) Spatial learning sculpts the dendritic arbor of adult-born hippocampal neurons. Proc Natl Acad Sci U S A 107:7963-7968. CrossRef Medline

Tronel S, Belnoue L, Grosjean N, Revest JM, Piazza PV, Koehl M, Abrous DN (2012) Adult-born neurons are necessary for extended contextual discrimination. Hippocampus 22:292-298. CrossRef Medline

Urcelay GP, Miller RR (2010) Two roles of the context in Pavlovian fear conditioning. J Exp Psychol Anim Behav Process 36:268-280. CrossRef Medline

Urcelay GP, Miller RR (2014) The functions of contexts in associative learning. Behav Processes 104:2-12. CrossRef Medline

Urushihara K, Miller RR (2009) Stimulus competition between a discrete cue and a training context: cue competition does not result from the division of a limited resource. J Exp Psychol Anim Behav Process 35:197211. CrossRef Medline

Wang LP, Kempermann G, Kettenmann H (2005) A subpopulation of precursor cells in the mouse dentate gyrus receives synaptic GABAergic input. Mol Cell Neurosci 29:181-189. CrossRef Medline

Young BJ, Otto T, Fox GD, Eichenbaum H (1997) Memory representation within the parahippocampal region. J Neurosci 17:5183-5195. Medline 